
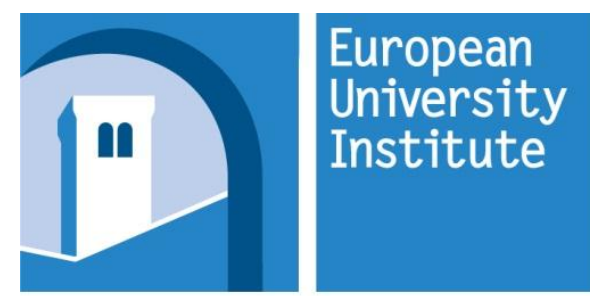

ROBERT

SCHUMAN

CENTRE FOR

ADVANCED

STUDIES

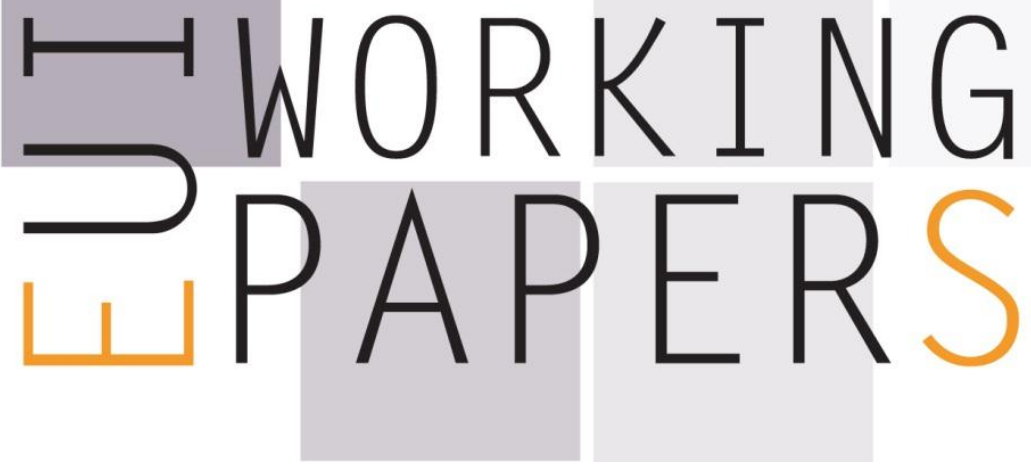

RSCAS 2013/53

Robert Schuman Centre for Advanced Studies Florence School of Regulation

Dividend Policy in Regulated Firms

Francisca Bremberger, Carlo Cambini, Klaus Gugler, Laura Rondi 

European University Institute

Robert Schuman Centre for Advanced Studies

Florence School of Regulation

\section{Dividend Policy in Regulated Firms}

Francisca Bremberger, Carlo Cambini, Klaus Gugler, and Laura Rondi

EUI Working Paper RSCAS 2013/53 
This text may be downloaded only for personal research purposes. Additional reproduction for other purposes, whether in hard copies or electronically, requires the consent of the author(s), editor(s). If cited or quoted, reference should be made to the full name of the author(s), editor(s), the title, the working paper, or other series, the year and the publisher.

ISSN 1028-3625

(C) Francisca Bremberger, Carlo Cambini, Klaus Gugler, Laura Rondi, 2013

Printed in Italy, July 2013

European University Institute

Badia Fiesolana

I - 50014 San Domenico di Fiesole (FI)

Italy

www.eui.eu/RSCAS/Publications/

www.eui.eu

cadmus.eui.eu 


\section{Robert Schuman Centre for Advanced Studies}

The Robert Schuman Centre for Advanced Studies (RSCAS), created in 1992 and directed by Stefano Bartolini since September 2006, aims to develop inter-disciplinary and comparative research and to promote work on the major issues facing the process of integration and European society.

The Centre is home to a large post-doctoral programme and hosts major research programmes and projects, and a range of working groups and ad hoc initiatives. The research agenda is organised around a set of core themes and is continuously evolving, reflecting the changing agenda of European integration and the expanding membership of the European Union.

Details of the research of the Centre can be found on:

http://www.eui.eu/RSCAS/Research/

Research publications take the form of Working Papers, Policy Papers, Distinguished Lectures and books. Most of these are also available on the RSCAS website:

http://www.eui.eu/RSCAS/Publications/

The EUI and the RSCAS are not responsible for the opinion expressed by the author(s).

\section{Florence School of Regulation}

The Florence School of Regulation (FSR) is a partnership between the Robert Schuman Centre for Advanced Studies (RSCAS) at the European University Institute (EUI), the Council of the European Energy Regulators (CEER) and the Independent Regulators Group (IRG). Moreover, as part of the EUI, the FSR works closely with the European Commission.

The objectives of the FSR are to promote informed discussions on key policy issues, through workshops and seminars, to provide state-of-the-art training for practitioners (from European Commission, National Regulators and private companies), to produce analytical and empirical researches about regulated sectors, to network, and to exchange documents and ideas.

At present, its scope is focused on the regulation of Energy (electricity and gas markets), of Communications \& Media, and of Transport.

This series of working papers aims at disseminating the work of scholars and practitioners on current regulatory issues.

\section{For further information}

Florence School of Regulation

Robert Schuman Centre for Advanced Studies

European University Institute

Via Boccaccio, 151

I-50133 Firenze

Tel.: +39055 4685751

Fax: +39055 4685755

E-mail: fsr@eui.eu

http://www.eui.eu/RSCAS/ProfessionalDevelopment/FSR/ 



\title{
Dividend Policy in Regulated Firms
}

\author{
Francisca Bremberger $^{1}$ \\ WU Vienna University of Economics and Business \\ Carlo Cambini $^{2}$ \\ Politecnico di Torino and EUI - Florence School of Regulation \\ Klaus Gugler \\ WU Vienna University of Economics and Business \\ Laura Rondi ${ }^{4}$ \\ Politecnico di Torino and CERIS-CNR
}

June 11, 2013

\begin{abstract}
We study the impact of different regulatory and ownership regimes on the dividend policy of regulated firms. Using a panel of 106 publicly traded European electric utilities in the period 1986-2010, we link payout and smoothing decisions to the implementation of different regulatory mechanisms (cost plus vs. incentive regulation) and to firm ownership (state vs. private). After controlling for the potential endogeneity of the regulatory mechanism, our results show that utilities subject to incentive regulation smooth their dividends less than firms subject to cost-based regulation and present higher impact effects and target payout ratios. This suggests that when managers are more sensitive to competition-like efficiency pressures following the adoption of incentive regulation, they adopt a dividend policy more responsive to earnings variability and more consistent with optimal cash management. These results, however, apply only to private utilities. If the state still has ultimate control, smoothing of dividends remains irrespective of the regulatory mechanism. It seems that corporate governance (i.e. state control) trumps regulation when it comes to dividend payout policy.
\end{abstract}

Keywords: Dividends, Lintner model, incentive regulation, electricity

JEL: G35, G38, L51, L94

\footnotetext{
${ }^{1}$ WU Vienna University of Economics and Business, Institute of Corporate Governance, Nordbergstrasse 15, 1090 Vienna, Austria. Tel: + 43-1-31336 5495, Email: Francisca.Bremberger@wu.ac.at

${ }^{2}$ Politecnico di Torino, DIGEP, Corso Duca degli Abruzzi, 24, 10129 Torino, Italy. Tel: + 39-0115647292, email: carlo.cambini@polito.it.

${ }^{3}$ WU Vienna University of Economics and Business, Institute for Quantitative Economics, Augasse 2-6, 1090 Vienna, Austria. Tel: + 43-1-31336 544. Email: Klaus.Gugler@wu.ac.at

${ }^{4}$ Corresponding author: Politecnico di Torino, DIGEP, Corso Duca degli Abruzzi, 24, 10129 Torino, Italy. Tel: +39-0115647232, Email: laura.rondi@polito.it, http://www.ceris.cnr.it/Rondi.htm
} 


\section{Introduction}

One of the most important financial decisions that a firm's managers face is on the amount and stability of dividends. Dividends have always been a bit of a puzzle in the theory of the firm. In the neoclassical world of Miller and Modigliani (1961) “dividends do not matter” which is to say that they drop out as a pure residual, once the optimal level of investment has been determined. Moreover, dividend smoothing is even more suspect: if one thought of dividends from the view of optimal cash flow management, one might expect them to be highly volatile. When profits are high, firms invest more and pay out large dividends. When profits are low, they cut dividends to maintain working capital. In the long run average dividend payments would be proportional to average profits, but in the short run they would bounce around. Thus, from the point of view of cash management, dividend smoothing since costly - is a puzzle.

In his seminal study, Lintner (1956) noticed that managers are particularly concerned with the stability of dividends. Half a century later, managers still appear to believe strongly that the market puts a premium on firms with a stable dividend policy (Brav et al. 2005). There have been many explanations of this observation including risk aversion on the part of investors, lack of investment opportunities or signalling theories (Black, 1976). Recently, a literature evolved explaining dividend smoothing by agency cost explanations, i.e. dividend policy as a consequence of the separation of ownership and control (Easterbrook, 1984 and, for comprehensive empirical evidence, Leary and Michaely, 2011). Agency theory predicts substantial and stable dividends. The higher dividends are, the less free cash flow there is, ceteris paribus, in managers' hands to spend on negative net present value projects. The higher dividends are, the greater is also the need to go to the capital market for new outside funds, and the greater the effectiveness of monitoring. If the primary function of dividends is to force firms into the capital market, regular and stable payouts are more valuable. Fudenberg and Tirole (1995) explain income and dividend smoothing based on incumbency rents. If managers enjoy private benefits from being in control, they, individually and rationally, smooth dividends. In bad times, they pay out too much dividends to lengthen their tenure. In good times, they are less concerned by their short-term prospects and information decay allows them to save for future bad times. Finally, La Porta et al. (2000) conjecture that minority shareholders press corporate insiders to pay dividends, since they cannot be sure to get a fair return particularly in countries where shareholder rights are not well developed. Consistent with an agency cost explanation of dividend smoothing, Gugler (2003) finds that target dividend levels, the smoothing of dividends, and the reluctance to cut dividends depend 
on the identity of the (ultimately) controlling owner. State-controlled firms engage in dividend smoothing and have the highest target payout ratios while, in marked contrast, dividend payments of family-controlled firms are not subject to dividend smoothing. Furthermore, state-controlled firms are most reluctant to cut dividends while family-controlled firms are least reluctant to cut dividends. More recently, Michaely and Roberts (2012), finding that privately owned firms smooth dividends and payout less than their publicly listed counterparts, suggest that the scrutiny of public capital markets, ownership structure and incentives altogether play key roles in shaping firm dividend policy.

In this paper we conjecture that there is still another factor that comes into play when we look at the dividend policy of large firms: regulation. When looking at public utility services, the state has two options to provide those services. First, the state himself can provide the services and own the assets so involved. Second, the state can privatise the companies providing these services and regulation accompanies this process: to prevent the abuse of natural monopoly positions, regulatory authorities are usually established that subject the utilities to regulation. An interesting hybrid construct is the partially state-owned company subject to regulation. The question that arises with such constructs is whether effective regulation can be expected if the state both owns part of the assets and sets up the regulatory framework. We analyse such set-ups in the electricity industry. In particular, we compare the dividend policy of firms that are partly owned by the state and subject to regulation with firms that are fully private and subject to regulation.

These firms are not only key for national economies in terms of aggregate investment (Guthrie, 2006) and market capitalisation (Bortolotti, Cambini and Rondi, 2013), they are also remarkable because of their generous dividend payments. A recent report by J.P. Morgan (2011) shows that telecom and electric utilities have been the highest-paying industries in the U.S. in the last years. Dividend payout, i.e. the ratio between dividends and net income, is 118\% for telecoms and 56\% in utilities, while dividend yield, i.e. annual dividends per share divided by the share price, is $5.3 \%$ for the telecom industry and $4.5 \%$ for the other utilities, which are the highest values among all sectors.

These firms are subject to regulatory oversight, a feature that most of the times has set them apart when studying dividend policy, the common explanation being that their dividend behaviour does not reconcile with current textbook explanations because regulated sectors are less risky, insulated from product and even capital markets' discipline and where regulators directly or indirectly may influence how much dividend they can pay. For example Moyer, Chatfield and Sisneros (1989) find that security analysts' monitoring activities are lower when 
the firm is a public utility. In general, the finance literature that examined the dividend behaviour of regulated firms focused on the role that dividend payouts play in the monitoring process to reduce equity agency costs within capital markets (Miller, 1986; Smith, 1986; and Hansen, Kumar and Shome, 1994).

The aim of this paper is to study regulated firms' dividend policy with a new perspective that investigates whether different types of regulatory contracts can influence firms' smoothing and payout decisions. To this purpose, we examine how firms respond to changes in regulatory mechanisms that are aimed at enhancing their efficiency as well as at shaking their "quite life". Since the European energy sector has been subject to significant regulatory and privatisation reforms, we use a large sample of European electric utilities from 1986 to 2010 to link their dividend behaviour to the implementation of new regulatory mechanisms, allowing for potential influences of their ownership status. Moreover, this paper also departs from the previous literature in that we account for the potential endogeneity of the regulatory policy.

Over the last thirty years, the EU energy sector underwent many reforms, mainly aimed at liberalising the market and at privatising the state-owned monopolies. The main purpose was (and still is) to raise firm efficiency and to improve the quality of service. While electric generation is already almost fully liberalised (and de-regulated) as well as privatised in most EU countries, transmission and distribution services are still subject to regulation either by independent regulatory agencies or by executive-branch commissions, and many transmission and distribution operators still remain partially (or fully) controlled by the state. ${ }^{5}$

Among market reforms that affect the provision of public utilities, the choice of the regulatory contracts is a key policy decision that in many countries has brought the implementation of modern regulatory mechanisms (Laffont, 1994): incentive regulation. Incentive regulation serves the purpose to raise the efficiency of energy utilities that had so far been regulated - both in the US and in Europe - through a cost-based regulatory mechanism. Mainly adopted to reduce managerial slack, these modern regulatory schemes are thought to provide powerful incentives to increase efficiency by leaving larger profits to the regulated operator. At the same time, earnings become more volatile and firms under incentive regulation are perceived to be riskier by the financial markets. ${ }^{6}$

Starting from the classic Lintner model, we modify the standard partial adjustment specification to take into account the potential effect of a regulatory policy change on firms'

\footnotetext{
${ }^{5}$ For an overview of the regulatory and privatisation reforms in the European electric sector, see Cambini, Rondi and Spiegel (2012).

${ }^{6}$ See the surveys by Armstrong and Sappington (2006 and 2007) and Joskow (2007).
} 
dividend behaviour. We argue that, under cost-based regulation, the regulated price moves with ex post costs which is why the firm has more stable cash flows, whereas under incentive regulation profits mostly depend on the firm's ability to achieve efficiency gains; hence firms are the "residual" claimants. The pressure to increase efficiency is stronger under incentive than under cost-based regulation, which should drive the behaviour of incentive regulated firms to smooth their dividends less than firms under cost-based regulation. Dividend flows are therefore likely to be more stable for firms under cost-based than under incentive regulation.

The reluctance of the national governments to release control and ownership of energy incumbents may be, in part, related to the reluctance to abandon the large dividend rights that accrue to the state as the main shareholder. Especially when the budget constraint tightens (as in the recent years in all Western economies), the “energy dividend” becomes a more or less safe and steady source of financing. Our next research question therefore asks whether the firm's ownership structure may also affect the dividend policy of electric utilities. We argue that the reasons why ownership is expected to matter for regulated firms' dividend policy are not only related to the classical agency problem as developed by Gugler (2003) or Michaely and Roberts, 2012), but also to government and political interference in utilities' real and financial decisions (Shleifer and Vishny, 1994; Shleifer, 1998; Bennedsen, 2000; and, for an empirical test on European firms, Bortolotti, Cambini and Rondi, 2013).

Our results show that, consistent with our theoretical model, the dividend behaviour of incentive and cost-based regulated utilities differs significantly. Throughout most specifications and econometric methods, electric utilities under incentive regulation are found to exhibit lower smoothing parameters and higher impact effects. Moreover, higher target payout ratios for incentive regulated firms are found in all GMM specifications. However, these results are only valid when the firms are privately controlled. In marked contrast, partially-state owned firms actually display larger smoothing of dividends when incentive regulation is introduced, while impact effects are unaltered, compared to state-controlled firms under cost-based regulation. This leads to a rise in target payout ratios for statecontrolled firms under incentive regulation. These results suggest that incentive regulation transfers more risk to regulated firms, making their managers more sensitive to competitionlike efficiency pressures, hence more likely to cut dividends when necessary, when also control is privatised. If control remains in state-hands, the effects of regulatory reform differ, at least with respect to dividend policy. 
To the best of our knowledge, this paper is the first systematic analysis of the interrelation between regulation, ownership and dividend payout policy. The outline of the paper is the following. In Section 2 we present the dividend model of smoothing and payout extended to account for regulatory regimes and we describe our estimation strategy. Section 3 describes the changing pattern of the regulatory framework in the European energy market, the sample and the data we use for the estimations. In Section 4 we present the main results. Section 5 summarises and concludes.

\section{Research Design and Estimation Strategy}

\subsection{A Model of Dividend Policy for Regulated Firms}

We start by assuming that firms set their dividend payout policy according to the partial adjustment model of Lintner (1956). Following the Lintner Model, dividends are the result of a partial adjustment of last year's dividends towards a target payout ratio. In more details, for any year $t$, the target level of dividends, $D_{i t}^{*}$ for firm $i$, is related to the current earnings, $E_{i t}$, through a desired payout ratio $\tau_{i}$ :

$$
D_{i t}^{*}=\tau_{i} E_{i t}
$$

In any given year the firm will only partially adjust their dividend policy towards the target dividend level. Hence, it results:

$$
D_{i t}-D_{i t-1}=a_{i}+\alpha_{i}\left(D_{i t}^{*}-D_{i t-1}\right)+u_{i t}
$$

where $D_{i t}-D_{i t-1}$ is the actual change in the dividend, $a_{i}$ is a constant, $\alpha_{i}$ measures the speed of adjustment and lies between zero and one, and $D_{i t}^{*}-D_{i t-1}$ is the desired change in the dividend. The closer $\alpha_{i}$ is to one, the faster the speed of adjustment is. $\left(1-\alpha_{i}\right)$ is called the Smoothing parameter, and $\tau_{i}$ is the Target Payout Ratio parameter, which gives the optimal percentage of profits for distribution via dividends. The constant term $a_{i}$ is generally positive and it reflects the greater reluctance to reducing vis-à-vis raising dividends, which is commonly observed. Finally, $u_{i t}$ represents the discrepancy between the observed change and that expected on the basis of the model. The adjustment process can be rewritten as: 


$$
D_{i t}=a_{i}+\alpha_{i} \tau_{i} E_{i t}+\left(1-\alpha_{i}\right) D_{i t-1}+u_{i t}
$$

where $\alpha_{i} \tau_{i}$, the coefficient on current earnings, is called the "impact effect". This leads to the following empirically testable equation:

$$
D_{i t}=a_{i}+\beta_{1} E_{i t}+\beta_{2} D_{i t-1}+u_{i t}
$$

and computation of the three parameters of interest, smoothing, impact effect and target payout ratio, as follows:

$$
1-\alpha_{i}=\beta_{2} \quad ; \tau_{i} \alpha_{i}=\beta_{1} ; \tau_{i}=\frac{\beta_{1}}{1-\beta_{2}}
$$

Recent empirical analyses on dividend policy show that dividend smoothing is highly affected by earnings volatility and company risk. In particular, Leary and Michaely (2011) empirically find that firms with high earnings and cash flow volatility, and therefore more risk, tend to smooth less. We directly incorporate this empirical evidence in our setting modifying the measure of the speed of adjustment in the following way:

$$
\bar{\alpha}_{i}=\alpha_{i}\left(1+\sigma_{i}\right)
$$

where $\alpha_{i}$ is again the standard measure of the speed of adjustment, and $\sigma_{i}$ is a measure of the earnings volatility of firm $i$. This assumes that the speed of adjustment increases as long as earnings volatility rises, and implies that we can rewrite Equation (2) as follows:

$$
D_{i t}-D_{i t-1}=a_{i}+\bar{\alpha}_{i}\left(D_{i t}^{*}-D_{i t-1}\right)+u_{i t}
$$

with $D_{i t}^{*}=\tau_{i} E_{i t}$. This leads to the following:

$$
D_{i t}=a_{i}+\alpha_{i}\left(1+\sigma_{i}\right) \tau_{i} E_{i t}+\left(1-\alpha_{i}\left(1+\sigma_{i}\right)\right) D_{i t-1}+u_{i t}
$$

This implies that the "adjusted” smoothing parameter becomes: 


$$
1-\alpha_{i}\left(1+\sigma_{i}\right)=\hat{\beta}_{2}
$$

Condition (6) shows that higher earnings volatility leads to a smaller smoothing parameter, in line with evidence by Leary and Michealy (2011).

We believe that this approach is particularly important in explaining dividend decisions in regulated utilities where earnings volatility is strongly correlated with the kind of regulatory contracts firms are subject to. The different contractual regimes adopted to regulate utilities all over the world range from the standard low powered incentives/cost-based mechanism - such as the rate of return regulation - to the more recent incentive regulatory schemes - such as the revenue or price cap mechanisms (see Laffont, 1994; Armstrong and Sappington, 2006 and 2007). To this aim, it is important to recall the scope and the effect of the introduction of different contractual types on firm performance.

The most famous cost-based regulatory mechanism is known as the rate of return regulation, whereby regulators fix the rate of return the utility can earn on its assets. With this form of contract, the regulators set the price the utility can charge so as to cover all main operating costs and to allow it to earn a specified rate of return. The regulated price can then be adjusted upward (downward) if the firm starts making a lower (higher) rate of return. In turn, this implies that this pricing scheme not only does not boost firm efficiency but it also reduces earnings volatility and guarantees financial integrity of the regulated firm (Armstrong and Sappington, 2006; Joskow, 2007).

Contrary to the standard cost-based mechanism, the purpose of incentive regulation is to encourage efficiency gains. By pursuing cost savings, managers can generate higher profits and thus benefit shareholders. However, incentive schemes change over time and are generally revised periodically by national regulators to avoid the regulated company to earn supernormal profits. This implies that the firms can maintain high profits only if the management succeeds in seeking out further cost savings. Incentive regulation ${ }^{7}$ may thus leave excess profits to the regulated operator, if the firm is able to meet the incentives set by the regulators constantly over time; but its adoption also shifts the risk of demand or cost fluctuations on the firm, increasing therefore the variability of the company earnings. Indeed, empirical evidence shows that on average the adoption of incentive mechanisms not only

\footnotetext{
7 Incentive regulation is usually implemented as price- or revenue-cap mechanisms or benchmarking (Littlechild, 1983), through the application of fixed-price contracts (Armstrong and Sappington, 2007). Sappington (2002) is a comprehensive survey of incentive regulation mechanisms and instruments. Joskow (2008) surveys incentive regulation schemes as adopted in the energy industry.
} 
leads to higher productivity but also to higher net profits (Ai and Sappington, 2002), higher volatility in earnings (Parker, 1997) ${ }^{8}$ and higher systematic risk (Alexander and Irwin, 1996; Grout and Zalewska, 2006) than the standard low-powered incentive cost-based mechanism.

From the above analysis, we therefore have the following testable hypothesis:

\section{$H_{1}$ (Dividend Smoothing): Firms under Incentive Regulation have lower smoothing parameters than firms under Cost-Based regulation.}

Thus, we argue that, under cost-based regulation, the regulated price moves with ex post costs which is why the firm has more stable cash flows, whereas under incentive regulation, profits mostly depend on the firm's ability to achieve efficiency gains; hence firms are the "residual" claimants. Dividend flows are therefore likely to be more stable for firms under cost-based than under incentive regulation. The pressure to increase efficiency is stronger under incentive regulation than under cost-based, which should drive the behaviour of incentive regulated firms to smooth their dividends less than firms under cost-based regulation.

However, there is one big qualification to this hypothesis, namely whether continuing state-control counteracts the efficiency effects of incentive regulation. Elected politicians are held accountable for all of the activities of government. They can be expected to have a particularly strong interest in seeing a steady flow of dividends from a company controlled by the state, since (1) dividends may suffice to convince citizens that the company is performing well, and (2) a steady stream of dividends reduces the cash flow in the hands of the managers (see Gugler, 2003). (3) The reluctance of the national governments to release control and ownership of energy incumbents may be, in part, related to the reluctance to abandon the large dividend rights that accrue to the state as the main shareholder. ${ }^{9}$ Especially when the budget constraint tightens (as in the recent years in all Western economies), the "energy dividend" becomes a safe and steady source of financing.

Our next research question therefore asks whether the firm's ownership structure may also affect the dividend policy of electric utilities. In particular, we expect that state-controlled firms continue to smooth their dividends despite of incentive regulation, since politicians

\footnotetext{
${ }^{8}$ Parker (1997) shows that after the introduction of incentive regulation profits of many UK utilities largely increase but they also start to fluctuate a lot both in the electricity and telecom sectors. On the contrary, in the gas industry the incumbent operator British Gas presented falling profits over time due to large restructuring costs and the excessive costs of the contracts for gas provision.

${ }^{9}$ There are several recent examples for this. Verbund, for example, a large Austrian electricity company left its dividend stable in 2011 despite a slight drop in profits (see Stock-Express.Com, 29 February, 2012). Verbund is $51 \%$ state controlled. The management of Verbund aims at a "target 50\% payout ratio".
} 
and/or controlling bureaucrats demand stable dividends. After all, (excessive) dividends, i.e. rent extraction from producers and/or consumers, represent a much more hidden way of increasing the funds available for politicians than direct taxation.

If incentive regulation leads to larger efficiency pressure, cash management should (must) also be optimised. If profits are high, dividend payouts should be high, if profits are low, dividend payouts should be low. Moreover, note that according to Moyer et al. (1992) regulated utilities use dividend payouts as a strategic instrument to obtain more favourable conditions on retail prices from the regulator. Hence, utilities may use their earnings to distribute larger payouts to affect the regulatory policy. ${ }^{10}$

We thus claim that the type of the regulatory contract also allows us to hypothesize on the impact effect.

\section{$\mathrm{H}_{2}$ (Impact Effect): Firms under Incentive Regulation have larger impact effect parameters than firms under Cost-Based regulation.}

Again, this analysis is largely confined to private firms. If incentive regulation does not imply the same efficiency and/or strategic implications for state-controlled firms than for private firms, we would also not expect hypothesis 2 to hold for them.

Previous studies (Moyer et al., 1992; Hansen et al., 1994) show that payout ratios of regulated utilities are typically higher than payout ratios for non-regulated industrial firms. According to these studies, regulatory oversight from national regulators insulates utility managers from the discipline of both the market for corporate control and the product market competition. However, while these factors help to explain why larger payout ratios are expected in utilities, they are not sufficient to explain the variation in dividend payouts across utilities.

The hypothesised effects of incentive regulation on the target payout ratio are more subtle. On the one hand, incentive regulation should reduce dividend smoothing, leading to lower target payout ratios, on the other hand the increased efficiency and/or strategic pressures of incentive regulation should lead to larger impact effects, and thus to larger target payout ratios (see equations (5)). Thus, ex ante we cannot determine which effect is larger, and we leave this to the empirical analysis. While the same arguments may apply to statecontrolled companies, one may argue that their target payout ratios unambiguously increase under incentive regulation. The reasons are that the rents so extracted from producers and/or

10 This is in line with the strategic use of leverage already shown in previous studies (Daspupta and Nanda, 1993; Bortolotti et al., 2011). 
consumers are a more opaque way to increase funds for politicians than direct taxation, and, what is more, high and stable dividends may be taken as a signal that the state-controlled companies are performing well and increase efficiency under incentive regulation.

\subsection{Estimation Strategy}

The theoretical framework developed in the previous section provides the hypotheses to be tested by our econometric analyses. Estimation of the Lintner partial adjustment model using panel data raises a number of econometric problems that only recently have been explicitly addressed and accounted for (see for example, Andres et al., 2009, and Khan, 2006). The first estimation problem is that the Net Profits (or Cash Flows) variable is likely to be correlated across firms with the firm-specific effect and that the lagged Dividends variable is most likely correlated with these firm-specific effects. To remove the firm-specific effect, the within-group estimator can be used, but then, because the fixed-effect transformation requires time-demeaning of all variables, the lagged dependent variable would remain correlated with the transformed disturbance term. To obtain consistent estimators, we thus use the first-difference transformation to eliminate the fixed effect and then apply the linear generalised method of moments (GMM) estimator developed by Arellano and Bond (1991) and Arellano and Bover (1995). This estimator is especially designed for panel data models where the lagged dependent variable is included and some of the regressors are potentially endogenous and lagged values of the dependent variable can be used as instruments, provided there is no serial correlation in the disturbance. More specifically, we use the dynamic System-GMM estimator (Arellano and Bond, 1991, and Blundell and Bond, 1998), which deals with situations where the lagged dependent variable is persistent (i.e. the autoregressive parameter is large). ${ }^{11}$

We modify the original Lintner model so as to allow for a change in dividend behaviour due to the regulatory regime, interacting both the lagged dividend and contemporaneous profits with a binary variable $I n c \operatorname{Reg}_{\text {it }}$, which is equal to 1 when the firm is

\footnotetext{
${ }^{11}$ This model estimates a system of first-differenced and level equations and uses lags of variables in levels as instruments for equations in first-differences and lags of first-differenced variables as instruments for equations in levels, for which the instruments used must be orthogonal to the firm-specific effects. For the validity of the GMM estimates it is crucial that the instruments are exogenous. We check that they are and report the appropriate tests: the Arellano and Bond (1991) autocorrelation tests to control for first-order and second-order correlation in the residuals, the two-step Sargan-Hansen statistic to test the joint validity of the instruments and the Difference-in-Hansen test of exogeneity of individual instruments to test the overidentifying restrictions for the external instruments. The Sargan-Hansen test is robust, but may be weakened if there are too many instruments with respect to the number of observations (see Roodman, 2006). Therefore, we follow a conservative strategy using no more than two lags of the instrumenting variables, so as to assure that the number of instruments is not greater than the number of firms. Standard errors are robust to heteroskedasticity and arbitrary patterns of autocorrelations within individuals.
} 
regulated by an incentive mechanism (price- or revenue-cap, or benchmarking), and 0 when a cost-based regime is in place. The estimation equation is therefore:

$$
D_{i t}=a_{0 i}+a_{1 i} D_{i t-1}+a_{2 i} D_{i t-1} \operatorname{Inc}_{\operatorname{Reg}}{ }_{i t-1}+a_{3 i} E_{i t}+a_{4 i} E_{i t} \operatorname{Inc}_{\text {Reg }}+\varepsilon_{i t}
$$

A further econometric issue is the potential endogeneity of the regulatory contracts low vs. high-powered incentive schemes - that is chosen by the regulator. Ideally, to deal with the endogeneity of the contract type within a static setting, we might use a standard instrumental variable estimator (as in Bortolotti, Cambini and Rondi, 2013, for a market-tobook regression model), but the presence of the lagged dependent variable, and the need to deal with the dynamic panel bias, rules out the 2SLS approach. Within the GMM framework we can also GMM-instrument the interacted Inc Reg, on the ground that the "contract type" is fundamentally a choice variable that arises through a process of bargaining between the regulator, the firms and eventually the government, ${ }^{12}$ where this bargaining process is influenced by the past performance (dividends and profits) of the firm (as in Wintoki, Linck and Netter, 2012). In addition, we can also count on external instruments and use a set of variables that account for domestic institutions and country specific features to instrument Inc Reg. For this purpose, we rely on characteristics that may influence the choice of a regulatory regime, and use country-specific, time-varying variables extensively used in the applied political economy literature and typically sourced from the World Bank database on Political Institutions (see Beck et al., 2001, for a detailed description of the variables). Herfindahl Gov., the Herfindahl Index Government, is the sum of the squared seat shares of all parties in the government and is expected to control for the internal cohesion of the executive hence the ability to make and enforce policy decisions. ORIENTATION is a time-varying variable which accounts for the political orientation of the executive in charge; it is equal to 1 when the executive is rightwing, 2 when it is centre, and 3 when it is leftwing. STABILITY is a survey-based measure that captures the extent of turnover of a government's key decision makers in any year and ranges from 0 (high stability) to 1 (low stability). CHECKS is an index for checks and balances incorporated into a political system that ranges from 1 (minimal checks) to 10 (maximal checks).

\footnotetext{
12 This view is consistent with the theoretical analysis by, for example, Besanko and Spulber (1992) and by anectodal evidence. In particular, according to the U.S. Supreme Court, the decision to adopt a specific regulatory contract "involves a balancing of the investor's and the consumers' interests" that should result in rates "within a range of reasonableness" (see Federal Power Comm. v. Hope Natural Gas Co., 320 U.S. 591,603 (1944)).
} 
Finally, we include firm ownership, in the form of a dummy, State Control, which is equal to 1 when the government directly and/or indirectly holds at least $25 \%$ of the firm ownership, and has therefore ultimate control. This variable is original and manually constructed by the authors, as further detailed in the data section below.

The role of firm ownership, and particularly state ownership, is multifaceted because it may be viewed as affecting both dividend (Gugler, 2003) and regulatory policies. We have noted that privatisation of transmission and distribution operators is far from complete and this reluctance to privatise for governments with tight budget constraints and rocketing debtto-GDP ratios may be attributed to the substantial dividends that these operators distribute. However, insofar as firm value is the present value of the stream of future dividends, the decisions whether to sell the firm now or to cash in the dividends forever only depends on the government's preference for privatisation proceeds vis-à-vis an ongoing stream of dividends. Conversely, to the extent that the government can interfere with regulatory decisions (such as the choice of the regulatory institution or of the regulatory mechanism, down to setting the regulated rates) to obtain a more favourable treatment for state controlled firms that results in a large dividend payout, state ownership can be viewed a key determinant of regulation policy. Thus, eventually, state ownership potentially should matter for dividend policy both directly via state-control of the company and indirectly via regulatory policy. In a first step, therefore, we use State Control as an instrument for Inc Reg, thereafter we additionally include State Control as a direct determinant of dividend payout policy.

To summarise we start by presenting the results from simple pooled-OLS regressions (with time dummies), and then proceed with fixed-effect estimates before turning to two sets of GMM-IV results. In the first set, in order to allow for the endogeneity of regulatory regime, we GMM instrument not only the lagged Dividends but also its interaction with Inc Reg; in the second one, we also account for the potential influence of domestic institutions on the choice of the regulatory policy and, accordingly, introduce a set of external instruments drawn from the recent political economy literature. In a last step, we look whether state control has also a direct effect on dividend payout policy.

For robustness, we repeat the empirical strategy using Cash Flows instead of Net Profits as suggested by Fama and Babiak (1968) and recently adopted by Andres et al. (2009). Our panel includes firms from several countries with different and time-varying tax laws with respect to fixed assets depreciations (equipment write-offs and allowances for accelerated depreciations which may be relevant for capital intensive electric utilities) as well as to legal reserves. With this alternative approach we try to allow for dividend decisions that are not 
based on published earnings only. Since results are very similar and robust, we confine the Cash Flow results to the appendix.

\section{Institutional Context, Data and Summary Statistics}

\subsection{Institutional Context}

In the last decades, the European Commission issued several directives in order to prompt national reforms that redesigned the legal and regulatory framework in the public utility sector, and in particular in the electricity industry. While until the early nineties, public utilities in Europe, with the only UK exception, were characterized by vertical integration, state monopoly and public ownership, the aim of such reforms was to raise efficiency, improve service quality, and spur infrastructure investment through the introduction of liberalization, privatization and new regulatory interventions.

Directive 96/92/EC built the basis for this significant reform of the European electricity market. Its main aim was to open national electricity markets and to prepare an integrated electricity market in Europe. The directive contained common rules for electricity generation, transmission and distribution, in order to induce convergence in production and in market structures in single member states. In addition to that, monopolistic (transmission and distribution) and potential competitive markets (generation and retail) were distinguished and member states were required to establish independent transmission grids. Directive 2003/54/EC, the acceleration guideline, required complete opening of national electricity markets by July 1st, 2007. Moreover, legal unbundling and an independent national regulatory authority were demanded for the first time. The third energy package, Directive 2009/72/EC, further increased the unbundling requirements. Member countries can now choose between three different unbundling models: ownership unbundling, an independent system operator or an independent transmission operator. Although the effects of the different unbundling methods are still discussed, most European countries already switched to ownership unbundling.

According to the EU legislator, privatisation and liberalisation should enhance efficiency and competition, reduce the consumer's dependency on few large suppliers and increase security of supply. With reference to firm ownership energy enterprises, the European Union encouraged member states' governments to shift from the classical vertically integrated and state-controlled set-up towards unbundling and (at least partial) privatisation. 
However, the EU Commission left the ultimate decision about utilities’ ownership entirely in the hands of national governments. As of 2012, privatization of public utilities within EU member states is far from complete, and central and local governments still hold majority and minority ownership stakes in many regulated utilities, particularly in Austria, France, Finland, Germany and Italy.

Concerning the regulatory framework for setting trasmission and distribution charges most of the European countries (except for the UK) initially started with a cost-based regulation. Nevertheless, switching to some kind of incentive regulation has been part of most regulatory reform processes worldwide (Vogelsang, 2002; Cambini and Rondi, 2010). The EU Directives did not impose any mandatory rule on the form of regulatory schemes, delegating the choice of the most appropriate regime to each national regulatory agency. For this reason, the regulatory mechanisms differ across countries and across market segments. They range from the typical cost-plus (mainly, rate of return) to incentive-based schemes, either in the form of price or revenues caps or through benchmarking (yardstick) competition. Within the electricity sector, the UK adopted incentive mechanisms in the early nineties in both distribution and transmission, while other countries - like Belgium, Hungary, Italy, Spain and Norway - switched later from rate of return to incentive based pricing in both segments. Austria, Denmark, Finland and Sweden shifted to incentive schemes only in distribution, Greece and France still rely only on cost-plus mechanisms while Germany switched to incentive regulation in 2010.

Figure 1 presents a timeline indicating the first introduction of incentive regulation in the electricity market (for distribution, transmission or both) of several European countries.

Figure 1: Timeline of the Introduction of Incentive Regulation

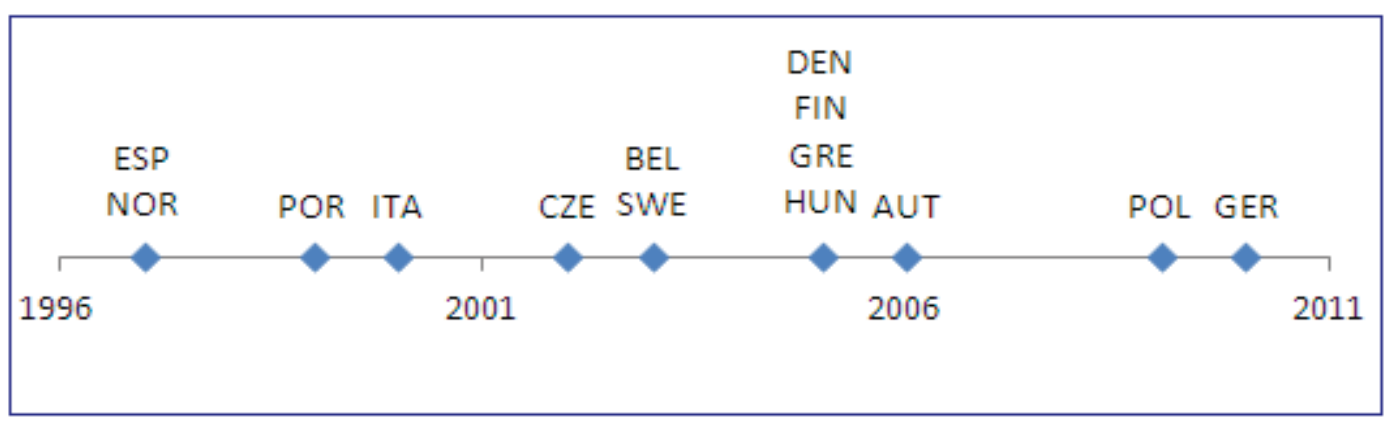




\subsection{Data and Summary Statistics}

The starting point of our sample creation were all firms listed in Worldscope, with a primary or secondary SIC code equal to 4911 "Electric services". ${ }^{13}$ We reviewed the selected sample by checking all included firms by hand and eliminating the ones which are mainly operating in different fields, like conglomerates or investment trusts. Subsequently, we created a dummy indicating whether the firms operate in distribution, transmission or production of electricity. We dropped all firms that are exclusively operating in electricity production, because these firms are not subject to regulation.

Finally, we obtain an unbalanced panel sample consisting of 106 firms operating in the European $^{14}$ electricity market in the period of 1986 to 2010. We use total common and preferred dividends paid to shareholders as dividend variable Dividends. For current earnings we use two different proxies: net income after preferred dividends for Net Profits of the firms and net profits plus depreciation, depletion and amortisation for Cash Flows of the firm (see the appendix). All variables are recorded in US\$, see Table 1 for definitions of all variables used.

To describe the regulatory regime the firms are facing, we constructed a dummy for incentive regulation (Inc Reg). This dummy contains a one if either transmission or distribution operates under incentive regulation, zero otherwise. The incentive regulation dummy is on the one hand used to create interaction terms with the main explanatory variables current earnings and lagged dividends and on the other hand for sub-sampling. Concerning the ownership data we constructed a dummy (State Control), indicating at least $25 \%$ state ownership. This threshold was chosen because $25 \%$ of shares establish a blocking minority in most European countries, which enables the owner to control important, strategic decisions of the enterprise. In creating the dummy we took the following procedure: If the state (governments at federal, state and local level) holds $25 \%$ or more of the shares of a firm, the dummy contains a one, zero otherwise. If a so state-controlled firm holds the majority of shares of another firm, this second firm is also marked as state-controlled. In that, direct and ultimate state ownership are considered. The necessary information was mainly collected from the homepages and annual reports of the firms.

\footnotetext{
${ }^{13}$ If a sales breakdown for segments is available SIC Code 1 would represent the business segment which provided the most revenue, and SIC Code 2 the second most. If a sales breakdown is not available the SIC Code is assigned according to the best judgment of Worldscope (Worldscope Database - Datatype Definitions Guide).

${ }^{14}$ Included countries: Austria, Belgium, Czech Republic, Denmark, Finland, Italy, Luxembourg, Norway, Poland, Portugal, Spain, Sweden, Switzerland, United Kingdom.
} 
Table 2 summarises descriptive statistics of all variables included in the regression analysis for the full sample (Panel A), highlights the yearly development of Inc Reg and State Control (Panel B), and presents means and mean difference tests in the variables between the different regulatory regimes (Panel C).

As reported in Panel A, firms pay on average around 230 Mio USD in Dividends out of Net Profits of 384 Mio USD (and Cash Flows of around 900 Mio USD). Around 33\% of firm-years operate under incentive regulatory schemes, while 67\% under cost-based type regimes. However, over time 74 out of the 106 firms face a regulatory regime switch from cost-based to incentive regulation. The average country in the sample locates around the centre of the political spectrum (mean Orientation of 2.05), enjoys broad internal cohesion in government (mean Herfindahl Gov. of 0.66), with a Checks average of around 4.19 (out of a maximum of 10), and faces political stability (mean Stability of 0.14). More than half of the firm-years (56.5\%) are under state control, and over time 28 out of the 106 firms face a switch in State Control.

A comparison of incentive versus cost-based regulated firms is particularly revealing (see panel C). Interestingly, if there is cost-based regulation in place, the percentage of companies still ultimately controlled by the state is much higher (68.7\%) than if incentive regulation is in place (34.8\%). Moreover, over time, incentive regulation gains and cost-based regulation looses importance, while the state gradually withdraws from control over time (see Panel B). This is a first indication that regulation and ownership/control are related.

\subsection{Profitability, Dividends and Volatility across Regulatory Regimes}

Our theoretical framework highlights the impact of earnings (profitability) variability and firm risk on dividend smoothing, while hinting at the potential differences of returns volatility for utilities operating under cost-based or incentive regulation. Thus, before turning to the estimation of the modified Lintner dividend model, we present evidence of firm heterogeneity of the level and variability of profitability and dividend payout across regulatory regimes (for a similar approach see for example Leary and Michaely, 2011, and Michaely and Roberts, 2012 and, specifically on regulated electric utilities, Hansen et al. 1994). We use Net Profits/Total Assets, Cash Flows/Total Assets, EBITDA/Total Assets (Return on Assets or ROA) and Net Profits/Equity (Return on Equity or ROE) as profitability measures and, to gauge dividend policy, we use both Dividend/Net Profits and Dividend/Cash Flows as measures of payout and Dividend/Total Assets as an alternative normalisation for dividends. In the lower part of Table 2, Panel C, we use the standard deviations of these variables to 
measure their volatility. Finally, to further document the differences in return variability (and firm risk), we include a comparison for Price Volatility, which is a measure of a stock's average annual price movement to a high and low from a mean price for each year. Figures 24 visually track the evolution over time of selected variables by regulatory regime.

Table 2, Panel C highlights the following differences between the sub-samples of incentive versus cost-based regulation. First, as already mentioned, the state is much more important as a controlling shareholder for cost-based regulated firms than for incentive regulated firms. Second, whether we measure them using Net Profits, Cash Flows or Ebitda, we find that firms under incentive regulation exhibit significantly higher profitability ratios than firms under cost-based regulation. This is consistent with the efficiency enhancing pressures of incentive regulation we hypothesized in the theory section. Third, the picture is a bit more nuanced with respect to dividend payout ratios. While Dividends as a share of Net Profits are (insignificantly) lower for incentive regulated firms (53.7\%) than for cost-based regulated firms (55.4\%), ${ }^{15}$ firms under incentive regulation pay out significantly larger shares as a percentage of Total Assets and Cash Flows. Thus, again consistent with our theoretical priors, the effects of incentive regulation on the dividend payout ratio are not clear-cut, since both lower smoothing but higher impact effects may be present at the same time. Finally, all comparisons of standard deviations of our profitability and dividend measures indicate, that the volatility of profitability and dividends goes up with the introduction of incentive regulation. We also find that stock price volatility, a market based proxy for firm risk, is also (significantly) higher for incentive regulated firms. The graphical evidence is in line with the mean differences tests. Figure 2 shows that profitability of incentive regulated firms as measured by the Return to Asset tend to be both higher and more volatile. This pattern is confirmed by Figure 3, which maps Dividend to Total Asset, and by Figure 4 where we graph Price Volatility.

Summarising, both the level and variability of profitability go up after the introduction of incentive regulation. This is consistent with efficiency enhancing pressures and firm riskiness going up due to becoming a "residual claimant” under incentive regulation. While this translates into a dividend policy, that is significantly more volatile whenever the firm is under incentive regulation, the dividend payout ratio does not necessarily go up. Thus, to ultimately judge the effects of incentive regulation one needs to look at the time profile of dividend payout policy, which we do below by estimating the Lintner model.

\footnotetext{
${ }^{15}$ Of course, the absolute amounts of dividends are higher under incentive regulation, since profits are so much higher.
} 


\section{Results}

\subsection{The Lintner Dividend Model for Regulated Firms}

As our unbalanced panel data set comprises different firms as well as varying time spans between 1986 and 2010, panel regression techniques have to be used to account for the characteristics of longitudinal data. We concentrate on estimating the pure Lintner Model, not accounting for other firm-differences (like size or tax differences between countries), which might be correlated with dividend payouts. Therefore, fixed effects (FE) specifications are theoretically more convincing than random effects specifications for estimating the Lintner Model. Moreover, as discussed in Section 3, the own past of dividend payouts is an important aspect of the Lintner Model for representing the adjustment process towards the target payout ratio. Including a lagged dependent variable may lead to biased estimates within the usual fixed effects panel framework. Consequently, although we report for comparison, pooledOLS and FE estimates, we focus our presentation of results on the system GMM estimator.

As a starting point, Table 3 reports the results for the full sample (Equation [4]), Table 5 allows for the differential impact of incentive vs. cost-based regulatory regimes by estimating the unrestricted model in Equation [7], while Table 4 reports the results of a regression analysis of the determinants of the choice of the regulatory mechanism (our quasifirst stage analysis). For all tables we quantify and report the corresponding model parameters: the coefficients of dividend smoothing (S), the impact effects (I) and the estimated target payout ratios (Tpr).

Table 3 shows estimation results for the whole unbalanced panel, where the coefficients on lagged Dividends and contemporaneous Net Profits are not interacted with the incentive regulation dummy. We note that the coefficient on the lagged dividend, $\left(1-\alpha_{i}\right)$, i.e. the coefficient of dividend smoothing, varies from 0.379 (FE) to 0.475 (GMM), thus the speed of adjustment $\left(\alpha_{i}\right)$ ranges between 0.525 and 0.621 . Impact effects are estimated of ranging between 0.172 (GMM) and 0.306 (OLS), thus target payout ratios range between 0.327 (GMM) and 0.560 (OLS) (Table 3a). All estimated coefficients are significant at the 1\% level of significance. As noted above, GMM estimates a system of first-differenced and level equations and uses lags of variables in levels as instruments for equations in first-differences and lags of first-differenced variables as instruments for equations in levels, for which the instruments used must be orthogonal to the firm-specific effects. Thus, for the validity of the GMM estimates it is crucial that the instruments are exogenous. Indeed, the autocorrelation tests for second-order correlation in the residuals, the two-step Sargan-Hansen statistic to test 
the joint validity of the instruments, and the Difference-in-Hansen test of exogeneity of individual instruments to test the overidentifying restrictions for the external instruments all suggest that our estimates are valid. Table A4 in the appendix reports the results when we use Cash Flows instead of Net Profits, and we find very similar results.

Before turning to the results from the unrestricted model that tests for the differences across regulatory regimes, Table 4 reports the results of regressions of Inc Reg on the set of external instruments used in the GMM regression of Table 5 (a "quasi first stage"). As explained in Section 3.2, the instruments are chosen among features of the domestic political institutions and the importance of state control in the industry, both of which may influence the choice of the regulatory regime. Because all institution variables vary only at the countryyear level, we estimate these regressions at the country-year level, and accordingly the number of observations goes down from the previous table. To deal with state control, we average State Control over all the electric utilities of each country and year, and thus Mean_State Control measures the percentage of companies under state control in each year in a given country in the electricity industry. In Table 4 we present the regression results for a within-group (fixed effects) model, a Logit model, and for a Logit regression estimated for the sub-sample of countries that report a switch in the regulatory regime from cost-based to incentive regulation. This "quasi" first stage analysis confirms our priors that ownership/control of the state and domestic political institutions play a significant role in affecting the choice of the regulatory regime. Incentive regulation schemes are less likely when state control of electric utilities is more pervasive and the government executive in charge is more leftwing. Moreover, incentive regulation appears to be more likely instituted when the parties in government are more unified and concentrated. No clear-cut results are obtained with institutional checks and balances (switching signs across specifications) and our political stability measure (insignificant).

We now turn to the key issue of this paper. Our prediction on the differing dividend behaviour of regulated firms according to the regulatory regime can be evaluated on the basis of Table 5. To recall, both the lagged Dividends and the Net Profits are interacted with Inc Reg, which is 1 when the firm is under incentive regulation (price or revenue-cap), and 0 when under cost-based regulation. The results show that the interacted Dividends terms (Dividends*Inc Reg) always carry a negative sign and are significant in columns (3) and (4), where the appropriate GMM estimator is used (in the OLS and fixed effects estimates of columns (1) and (2) the coefficients on the lagged Dividends terms are downwardly biased). The coefficients are similar whether or not we include the external instruments. Thus, we find 
clear evidence that the past level of dividends has a higher impact on this year's dividends for cost-based regulated utilities than for incentive regulated firms. Moreover, for the GMM regressions the coefficients on the Net Profits (Net Profits* Inc Reg) interaction terms enter significantly with positive signs. As predicted by our theoretical framework, therefore, dividend smoothing is less prevalent and impact effects are higher for firms that are subject to a regulatory scheme that encourages efficiency gains. Table 5a shows that for the GMM regressions the resulting target payout ratios are higher for incentive regulated firms than for cost-based regulated utilities, thus the increase in the impact effects outweighs the drop in dividend smoothing. Corresponding tests confirm a significant difference of the target payout ratios in the GMM specifications. Table A5 in the appendix reports the results when we use Cash Flows instead of Net Profits, and again we find very similar results.

Summarising, our results of a higher speed of adjustment and impact effects for incentive regulated firms confirm that these firms are less reluctant to cut dividends when necessary, and suggest that incentive regulatory schemes lead firms to a dividend policy more responsive to earnings variability and more consistent with efficiency-enhancing pressures. In addition, we find that, particularly in the columns reporting the consistent GMM estimates, the target payout ratios for incentive regulated firms tend to be higher than those of cost-based regulated firms.

\subsection{Dividend Policy of Regulated Firms: Does Ownership Matter?}

The first stage analysis in Table 4 has drawn our attention to the role of state control for the choice of the regulatory regime, and this may call into question whether, after all, ultimate state control may also directly influence the dividend policy of the regulated firms (see Gugler 2003, for example). Now, we take a further step and explore whether government control may cause the dividend policy to differ within different regulatory regimes.

As discussed in Section 3.2, the reluctance of national governments to release control and ownership of energy incumbents may be, in part, related to the reluctance to abandon the large dividend rights that accrue to the state as the main shareholder. In particular, one may postulate that politicians could exert their influence and demand high and stable dividends, even when the firm is subject to incentive regulation (which we have found to reduce dividend smoothing on average for all firms), to obtain funds for their purposes without the need to directly tax their electorate.

In Table 6 we report a set of statistics and mean difference t-tests similar to Table 2, but differentiating by state control as well as by regulatory regime. We note that private firms 
tend to be more profitable when they are under incentive regulation than under cost-based regulation, but that the same cannot be said for state controlled firms, corroborating our prior that incentive regulation does not entail the same efficiency pressures for firms when they remain under state control than when they are privatised. The picture from dividend payout ratios is less straightforward. Private firms seem to pay lower dividends under Incentive regulation than under cost-based regulation when we look at Dividends/ Net Profits, but more when looking at Dividends/ Cash Flows or Dividends/ Total Assets. This contrasts to state controlled firms which unambiguously display larger dividend payout ratios under incentive regulation than under cost-based regulation.

In Table 7 we present the regression results introducing the four-way interactions into the Lintner model - Inc State, Inc Private, and Cost Private with Cost State as the base category. Although we can rely on a large enough sample, the precision of the estimates from this four-way distinction goes down. Since the instrument count soars (see Roodman, 2006, for a warning about the problem of too many instruments) due to the many lagged dividend interactions, we also present a set of results where we deliberately do not GMM instrument the interacted terms (see column 5). Comfortingly, we find that the results remain similar.

The regression results in Table 7 suggest that the dividend policy, and particularly the smoothing behaviour, is significantly different between state and private utilities, even when they are subject to the same regulatory regime. The strongest result is undoubtedly that the lower smoothing parameters we had registered for utilities under incentive regulation appear to be completely due to private firms, while state firms continue to smooth dividends regardless of the regulatory regime. ${ }^{16}$ Table 7 a points out that smoothing parameters for private firms operating under incentive regulation are very low and insignificant in all specifications. Thus, we find some evidence that private firms under incentive regulation even stop targeting dividends at all and exclusively link dividend policy to current earnings. Together with the results on impact effects, which are not significantly different from each other, we obtain consistent evidence for the conjecture that state firms are seen as a source of stable dividends by the government, irrespective of the regulatory regime.

Overall the results suggest that the response to incentive regulation is dampened when the firm is partially owned by the state. Thus, the state appears to find ways to not only indirectly influence dividend payout policy via determining regulatory policy, but also to directly influence dividend policy via state control of the utility.

\footnotetext{
${ }^{16}$ The results with Cash Flows instead of Net Profits are similar, in that they show that private firms under incentive regulation tend to smooth significantly less, but also provide some evidence of lower smoothing for private firms under cost-based regulation (see Table A6 in the appendix).
} 


\section{Conclusion}

Regulated firms, and among them electric utilities, generally distribute very generous dividends to their shareholders. Notwithstanding this, dividend policy in regulated firms attracted little attention by the existing literature. We argue that this neglect is misplaced, since regulated industries provide a rich testing ground for theories of the firm, such as the relation of regulation and ownership, and the effects on key corporate finance decisions like the dividend pay-out decision.

The aim of this paper is to shed light on these issues via estimating the Lintner model of dividends for an unbalanced panel of 106 firms from seventeen European countries operating in the regulated segments of the electricity market (distribution and transmission). We unearth important differences in the dividend payout policy, i.e. the smoothing of dividends, impact effects and target payout ratios, of companies subject to different regulatory (incentive vs. non incentive) and corporate governance (state vs. private control) regimes. The observed time span ranges from 1986 to 2010 and covers a period of deep market reforms for the European energy sector.

We first extend the partial adjustment "behavioural" model by Lintner (1956) to take into account of the potential effect of a regulatory regime change on firms' earnings and their variability. We then test our predictions with our original dataset, allowing for the dynamic panel data bias as well as for the potential endogeneity of incentive regulation. Our results show that dividend smoothing, impact effects and therefore target payout ratios are sensible to the regulatory regime companies face. We find that electric utilities subject to incentive regulation smooth their dividends less and respond more readily to profit changes than those subject to cost-based regulation. This implies that incentive regulation leads dividend policy to be more responsive to earnings variability and more consistent with efficiency-enhancing pressures. These results are confirmed when we also account for the potential endogeneity of the regulatory mechanism, when we use cash flows instead of net profits and when we conduct sub-samples’ analyses.

The lower smoothing of dividends under incentive regulation is entirely due to private firms, however. We find even some evidence that private firms operating under incentive regulation stop targeting dividends at all and exclusively link current dividends to current earnings. In contrast to that, state controlled (i.e. partially state owned) firms continue to smooth their dividends, despite moving from cost-based to incentive regulation. One reason 
may be that obtaining excessive and stable dividends is a more hidden way to enforce political preferences than direct taxation. 


\section{References}

Ai, C. and D.E.M. Sappington (2002), "The Impact of State Incentive Regulation on the U.S.

Telecommunications Industry”, Journal of Regulatory Economics, 22(2), 107-132

Alexander I. and T. Irwin (1996), “Price Caps, Rate-of-Return Regulation, and the Cost of Capital”, Private Sector, note n. 87, The World Bank, Washington D.C.

Andres C., A. Betzer, M. Goergen and L. Renneboog (2009), "Dividend Policy of German Firms. A Panel Data Analysis of Partial Adjustment Models”, Journal of Empirical Finance, 16, 175-187

Arellano M. and S. Bond (1991), “Some Tests of Specification for Panel Data: Monte Carlo

Evidence and an Application to Employment Equations,” Review of Economic Studies, 58(2), 277-297.

Arellano M. and O. Bover (1995), “Another Look at the Instrumental-Variable Estimation of Error-Components Models,” Journal of Econometrics, 68, 29-51

Armstrong, M. and D. Sappington (2006), “Regulation, Competition and Liberalization”, Journal of Economic Literature, XLIV, 325-366

Armstrong, M. and D.E.M. Sappington (2007) "Recent Developments in the Theory of Regulation,” in M. Armstrong and R. Porter (eds.), Handbook of Industrial Organization (Vol. III), Elsevier Science Publishers: Amsterdam.

Beck T., G. Clarke, A. Groff, P. Keefer and P. Walsh (2001), “New Tools in Comparative Political Economy: The Database of Political Institutions”, World Bank Economic Review, 15(1), 165-176.

Bennedsen M. (2000), “Political Ownership”, Journal of Public Economics, 76, 559-581.

Besanko D. and D. Spulber (1992), “Sequential Equilibrium Investment by Regulated Firms”, Rand Journal of Economics, 23, 53-170

Black, F. (1976), “The Dividend Puzzle”, Journal of Portfolio Management 2, 5-8.

Blundell R. and S. Bond (1998), "Initial Conditions and Moment Restrictions in Dynamic Panel Data Models,” Journal of Econometrics, 87, 115-143

Bortolotti B., C. Cambini, L. Rondi, and Y. Spiegel (2011), "Capital Structure and Regulation: Do Ownership and Regulatory Independence Matter?”, Journal of Economics and Management Strategy, 20(2), 517-564.

Bortolotti B., Cambini C., and L. Rondi (2013), “Reluctant Regulation”, Journal of Comparative Economics, forthcoming. 
Brav, A., Graham, J.R., Harvey C.R., and Michealy R., (2005), "Payout Policy in the $21^{\text {st }}$ Century”, Journal of Financial Economics, 77, 483-527.

Cambini C. and L. Rondi (2010), “Incentive Regulation and Investment: Evidence from European Energy Utilities”, Journal of Regulatory Economics, 38, 1-26.

Cambini C. Rondi L. and Y. Spiegel (2012), “Investment and the Strategic Role of Capital Structure in Regulated Industries: Theory and Evidence”, (2012), in J. Harrington, Y. Katsoulacos and P. Regibeau (Eds.), Recent Advances in the Analysis of Competition Policy and Regulation, E. Elgar Publishing.

Dasgupta S. and V. Nanda (1993), “Bargaining and Brinkmanship - Capital Structure Choice by Regulated Firms”, International Journal of Industrial Organization, 11(4), 475-497

Domah, P.D. and M.G. Pollitt (2001) “The Restructuring and Privatisation of the Regional Electricity Companies in England and Wales: A Social Cost Benefit Analysis,” Fiscal Studies, 22:107-146.

Easterbrook, F.H. (1984) Two agency cost explanations of dividends. American Economic Review, 74(4), 650-659.

Estache, A. and M. Rodriguez-Pardina (1998) "Light and Lightening at the End of the Public Tunnel: The Reform of the Electricity Sector in the Southern Cone," World Bank Working Paper, May.

Fama E.F. and H. Babiak (1968), “Dividend Policy: An Empirical Analysis”, Journal of the American Statistical Association, 63(324), 1132-1161.

Fudenberg D. and J. Tirole (1995), “A Theory of Income and Dividend Smoothing Based on Incumbency Rents”, Journal of Political Economy, 103, 75-93.

Grout P.A. and A. Zalewska (2006), “The Impact of Regulation on Market Risk”, Journal of Financial Economics, 80, 149-184

Gugler K. (2003), “Corporate Governance, Dividend Smoothing, and the Interrelation between Dividends, R\&D, and Capital Investment,” Journal of Banking and Finance, 27/7, $1297-1321$.

Guthrie, G. (2006), “Regulating Infrastructure: The Impact on Risk and Investment”, Journal of Economic Literature, 44(4), 925-972.

Guttman I., O. Kadan and E. Kandel (2010), ”Dividend Stickiness and Strategic Pooling”, The Review of Financial Studies, 23, 4455-4495 
Hansen R.S., R. Kumar and D.K. Shome (1994), “Dividend Policy and Corporate Monitoring: Evidence from the Regulated Electric Utility Industry”, Financial Management, 23(1), 16-22.

J.P Morgan (2011), Dividends: the 2011 Guide to Dividend Policy Trends and Best Practices. Corporate Finance Advisory, January.

Joskow, P.L. (2007), “Regulation of Natural Monopolies”, in A. M. Polinsky and S. Shavell (eds.), Handbook of Law and Economics, Elsevier Science Publishers: Amsterdam

Joskow, P.L. (2008) "Incentive Regulation and Its Application to Electricity Networks,” Review of Network Economics, 7(4): 547-560.

Khan T. (2006), “Company Dividends and Ownership Structure”, Economic Journal, 116, 172-189.

Kumar P. and B. Lee (2001), “Discrete Dividend Policy with Permanent Earnings”, Financial Management, 30, 55-76.

La Porta, R., Lopez-de-Silanes, F., Shleifer, A., Vishny, R., (2000). “Agency problems and dividend policies around the world.” Journal of Finance 55 (1), 1-33

Laffont J.-J., (1994), “The New Economics of Regulation Ten Years After”, Econometrica, 62(3): 507-537.

Leary M.T. and R. Michaely (2011), "Determinants of Dividend Smoothing: Empirical Evidence”, The Review of Financial Studies, 24(10), 3197-3249.

Lintner, J. (1956). "Distribution of incomes of corporations among dividends, retained earnings and taxes,” American Economic Review, 46 (2), 97-113.

Littlechild, S. C. (1983), Regulation of British Telecommunication Profitability, HMSO, London.

Michaely R., and M.R. Roberts (2012), “Corporate Dividend Policies: Lessons from Private Firms”, Review of Financial Studies, 25(3), 711-746.

Miller M.H. (1986), “Behavior Rationality in Finance: The Case of Dividends,” Journal of Business, 5451-5468.

Miller, M.H., Modigliani, F., (1961). “Dividend policy, growth, and the valuation of shares.” Journal of Business, 34, 235-264.

Moyer R.C., R.E. Chatfield, and P.M. Sisneros (1989), "Security Analyst Monitoring Activity: Agency Costs and Information Demands,” Journal of Financial and Quantitative Analysis, 24, 503-512.

Moyer R.C., Rao R., and N. Tripathy (1992), “Dividend Policy and Regulatory Risk: A Test of the Smith Hypothesis”, Journal of Economics and Business, 44, 127-134. 
Newbery, D., and M. Pollitt, (1997) “The Restructuring and Privatization of Britain’s CEGB - Was it Worth It?” Journal of Industrial Economics, 45, 269-303.

Parker D. (1997), "Price Cap Regulation, Profitability and Returns to Investors in the UK Regulated Industries”, Utilities Policy, 6(4), 303-315.

Roodman D. (2006), "How to Do xtanbond2: An Introduction to "Difference” and "System” GMM in Stata,” The Center for Global Development, WP n. 103.

Sappington, D.E.M. (2002), Price Regulation and Incentives, in M. Cave, S. Majumdar and I. Vogelsang (eds.), Handbook of Telecommunications Economics, North Holland, Elsevier Publishing, Amsterdam.

Shleifer, A. (1998), “State versus Private Ownership”, Journal of Economic Perspectives, 12(4): 133-150.

Smith C.W. (1986), "Investment Banking and the Capital Acquisition Process”, Journal of Financial Economics, 15, 2-29

Volgelsang I. (2002), "Incentive Regulation and Competition in Public Utility Markets: A 20Year Perspective”, Journal of Regulatory Economics, 22(1), 5-27.

Wintoki M.B., Linck J.S. and J.M. Netter (2012), “Endogeneity and the Dynamics of Internal Corporate Governance”, Journal of Financial Economics, 105, 581-606 
Figure 2 - Return on Assets (Ebitda/Total Assets)

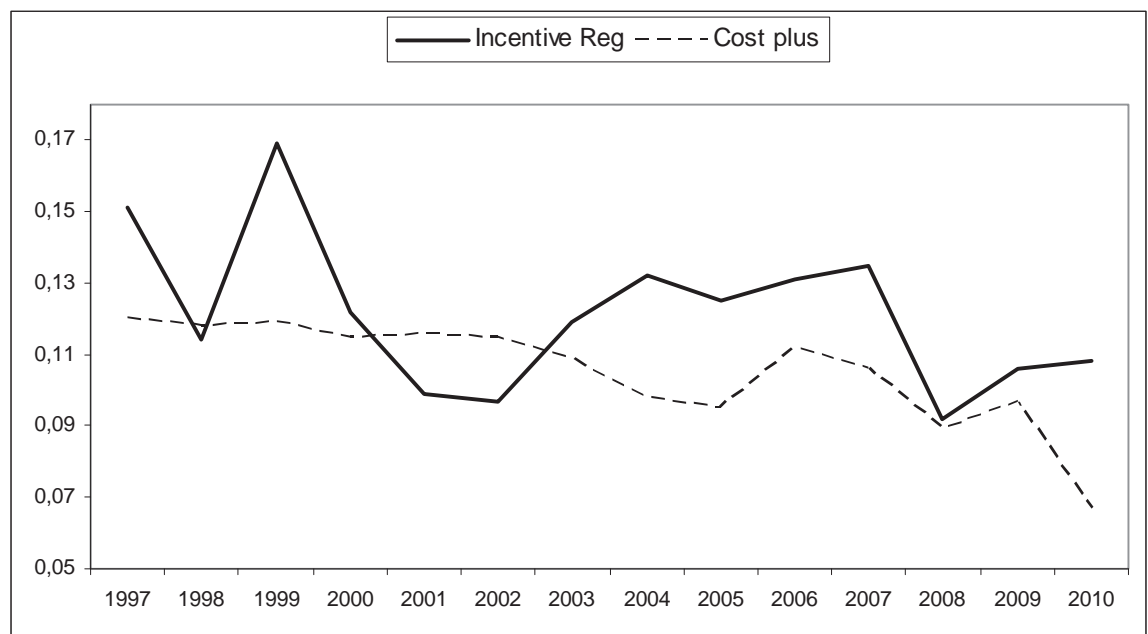

Figure 3 - Dividends/Total Assets

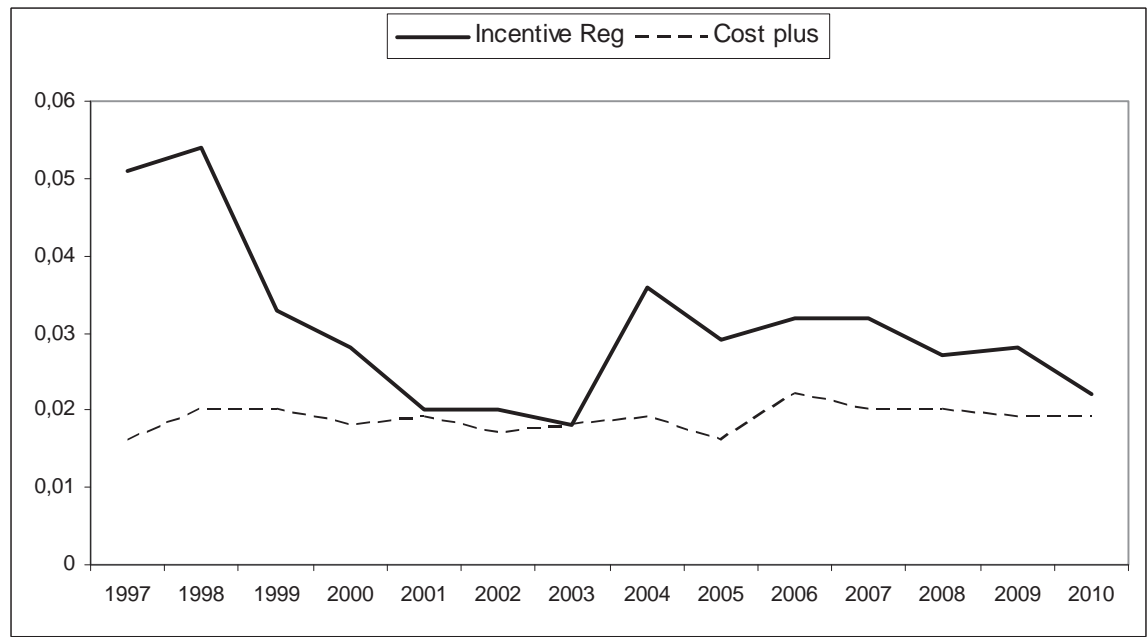

Figure 4 - Price Volatility

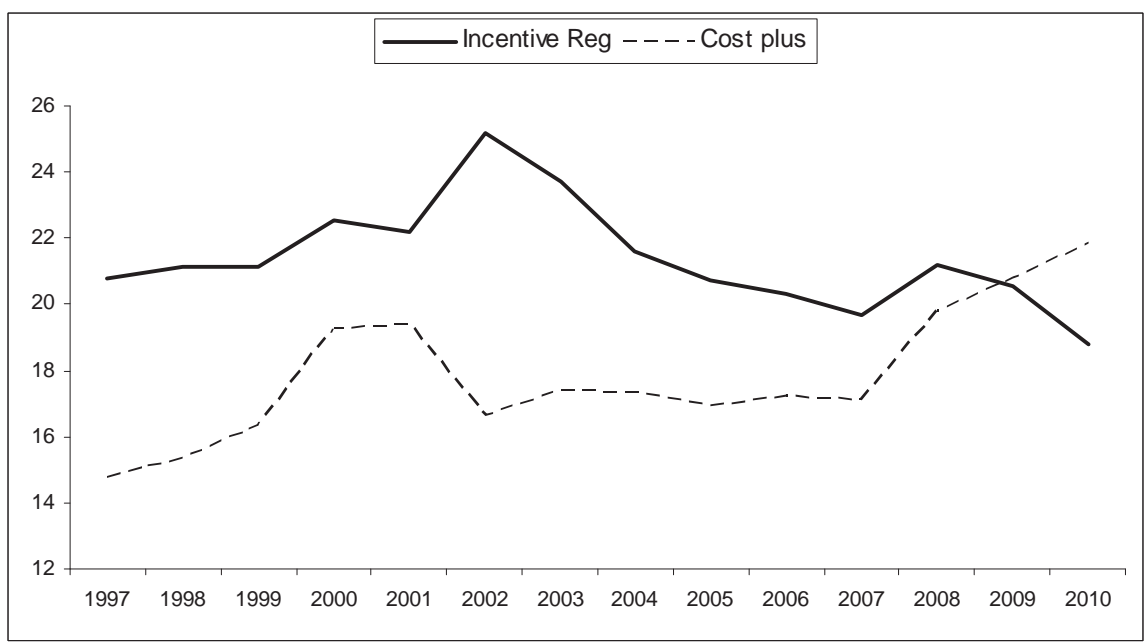


Table 1: Variable definitions and sources

\begin{tabular}{|c|c|c|}
\hline Variable Name & Source & Definition \\
\hline Dividends & Worldscope & $\begin{array}{l}\text { Total common and preferred dividends paid to shareholders of the company } \\
\text { (1000 U.S.\$). }\end{array}$ \\
\hline Net Profits & Worldscope & $\begin{array}{l}\text { Net income after preferred dividends that the company uses to calculate its } \\
\text { basic earnings per share (1000 U.S.\$). }\end{array}$ \\
\hline Dividend Payout Ratio & & Actual dividend payout ratio, computed as dpr=Dividends/Net Profits. \\
\hline Cash Flows & Worldscope & Net Profit plus depreciation, depletion and amortisation (1000 U.S.\$). \\
\hline Total Assets & Worldscope & Total assets of the company (1000 U.S.\$). \\
\hline Total Liabilities & Worldscope & All short and long term obligations (1000 U.S.\$). \\
\hline Ebitda & Worldscope & Earnings before interest, taxes and depreciation (1000 U.S.\$). \\
\hline Market Capitalisation & Worldscope & $\begin{array}{l}\text { Total market value of the company based on year end price and number of } \\
\text { shares outstanding (1000 U.S.\$). }\end{array}$ \\
\hline Tobin’s Q & & $\begin{array}{l}\text { Computed with variables from Worldscope as } \\
\text { Tobin’s Q=(Market Capitalisation +Total Liabilities)/ Total Assets. }\end{array}$ \\
\hline Leverage & & $\begin{array}{l}\text { Computed with variables from Worldscope as } \\
\text { Leverage }=\text { Total Liabilities/ Total Assets. }\end{array}$ \\
\hline Price Volatility & Worldscope & $\begin{array}{l}\text { A measure of a stock's average annual price movement to a high and low } \\
\text { from a mean price for each year. }\end{array}$ \\
\hline Inc Reg & $\begin{array}{l}\text { Regulatory } \\
\text { Authorities }\end{array}$ & $\begin{array}{l}\text { Self-constructed dummy, indicating whether the firm is operating under } \\
\text { incentive regulation (1) or not (0). }\end{array}$ \\
\hline State Control & $\begin{array}{l}\text { Annual } \\
\text { Reports }\end{array}$ & $\begin{array}{l}\text { Self-constructed dummy, indicating at least } 25 \% \text { state ownership (direct and } \\
\text { ultimate). }\end{array}$ \\
\hline Mean_State Control & & Computed as the yearly mean of the State Control dummy by nation. \\
\hline Orientation & DPI2009 & $\begin{array}{l}\text { A time-varying variable which accounts for the political orientation of the } \\
\text { executive in charge: (1) for rightwing, (2) for centre and (3) for leftwing. }\end{array}$ \\
\hline Herfindahl Gov. & DPI2009 & $\begin{array}{l}\text { Herfindahl Index Government: The sum of the squared seat shares of all } \\
\text { parties in the government. }\end{array}$ \\
\hline Stability & DPI2009 & $\begin{array}{l}\text { A survey-based measure that captures the extent of turnover of a } \\
\text { government's key decision makers in any year and ranges from (0) high } \\
\text { stability to (1) low stability. }\end{array}$ \\
\hline Checks & DPI2009 & $\begin{array}{l}\text { An index for checks and balances incorporated into a political system that } \\
\text { ranges from (1) minimal checks to (10) maximal checks. }\end{array}$ \\
\hline
\end{tabular}

Note: DPI2009 stands for Database of Political Institutions, World Bank 
Table 2 - Descriptive statistics - (106 electric utilities, period 1986-2010)

Panel A: Full Sample

\begin{tabular}{|c|c|c|c|c|c|}
\hline & Mean & sd & Min & Max & Obs. \\
\hline \multicolumn{6}{|l|}{ Political Institutions } \\
\hline Orientation & 2.048 & 0.932 & 1.00 & 3.00 & 356 \\
\hline Herfindahl Gov. & 0.658 & 0.274 & 0.18 & 1.00 & 384 \\
\hline Stability & 0.138 & 0.272 & 0.00 & 1.00 & 383 \\
\hline Checks & 4.185 & 1.399 & 1.00 & 10.00 & 384 \\
\hline \multicolumn{6}{|l|}{ Firm Characteristics } \\
\hline Inc Reg & 0.327 & 0.469 & 0.00 & 1.00 & 2650 \\
\hline State Control & 0.565 & 0.496 & 0.00 & 1.00 & 2027 \\
\hline Log_ Total Assets & 14.613 & 2.026 & 6.75 & 19.65 & 1580 \\
\hline Tobin’s Q & 1.300 & 0.563 & 0.35 & 5.99 & 1425 \\
\hline Leverage & 0.573 & 0.186 & 0.00 & 1.15 & 1580 \\
\hline \multicolumn{6}{|l|}{ Profitability } \\
\hline Net Profits (abs.) & 384351.929 & 1042573.029 & -2723518.50 & 12028613.00 & 1579 \\
\hline Cash Flows (abs.) & 905844.745 & 2011819.163 & -2162773.00 & 17316560.00 & 1572 \\
\hline Net Profits/ Total Assets & 0.041 & 0.047 & -0.55 & 0.35 & 1578 \\
\hline Cash Flows/ Total Assets & 0.087 & 0.051 & -0.54 & 0.38 & 1571 \\
\hline Net Profits/ Equity & 0.114 & 0.110 & -0.83 & 0.91 & 1566 \\
\hline Ebitda/ Total Assets & 0.120 & 0.059 & -0.53 & 0.52 & 1567 \\
\hline \multicolumn{6}{|l|}{ Dividends } \\
\hline Dividends (abs.) & 229028.942 & 677984.611 & 0.00 & 8945529.00 & 1537 \\
\hline Dividends/ Total Assets & 0.022 & 0.028 & 0.00 & 0.41 & 1537 \\
\hline Dividends/ Net Profits & 0.549 & 0.434 & 0.00 & 3.76 & 1480 \\
\hline Dividends/Cash Flows & 0.238 & 0.207 & 0.00 & 1.30 & 1501 \\
\hline Price Volatility & 18.270 & 6.516 & 0.00 & 43.43 & 914 \\
\hline N.Firms [N. Obs.] & $106[2650]$ & & & & \\
\hline
\end{tabular}

Note: The section Political Institution refers to a nation-year basis.

Panel B: Time Structure of Inc Reg and State Control

\begin{tabular}{ccc}
\hline & & \\
& Inc Reg & State Control \\
\hline 1986 & $13.21 \%$ & $77.46 \%$ \\
1987 & $13.21 \%$ & $76.06 \%$ \\
1988 & $13.21 \%$ & $75.00 \%$ \\
1989 & $13.21 \%$ & $75.00 \%$ \\
1990 & $13.21 \%$ & $61.33 \%$ \\
1991 & $13.21 \%$ & $61.33 \%$ \\
1992 & $13.21 \%$ & $60.53 \%$ \\
1993 & $13.21 \%$ & $58.97 \%$ \\
1994 & $13.21 \%$ & $56.25 \%$ \\
1995 & $13.21 \%$ & $54.22 \%$ \\
1996 & $13.21 \%$ & $55.43 \%$ \\
1997 & $23.58 \%$ & $54.95 \%$ \\
1998 & $23.58 \%$ & $52.69 \%$ \\
1999 & $24.53 \%$ & $53.76 \%$ \\
2000 & $33.02 \%$ & $52.17 \%$ \\
2001 & $33.02 \%$ & $54.02 \%$ \\
2002 & $44.34 \%$ & $54.02 \%$ \\
2003 & $50.94 \%$ & $53.41 \%$ \\
2004 & $50.94 \%$ & $52.81 \%$ \\
2005 & $58.49 \%$ & $51.90 \%$ \\
2006 & $61.32 \%$ & $45.45 \%$ \\
2007 & $61.32 \%$ & $45.45 \%$ \\
2008 & $61.32 \%$ & $46.75 \%$ \\
2009 & $62.26 \%$ & $47.37 \%$ \\
2010 & $83.02 \%$ & $47.37 \%$ \\
\hline
\end{tabular}

Note: Percentages refer to firms under incentive regulation and state control over the total of included firms respectively. 
Panel C: Firms under Incentive vs. Cost-Based Regulation

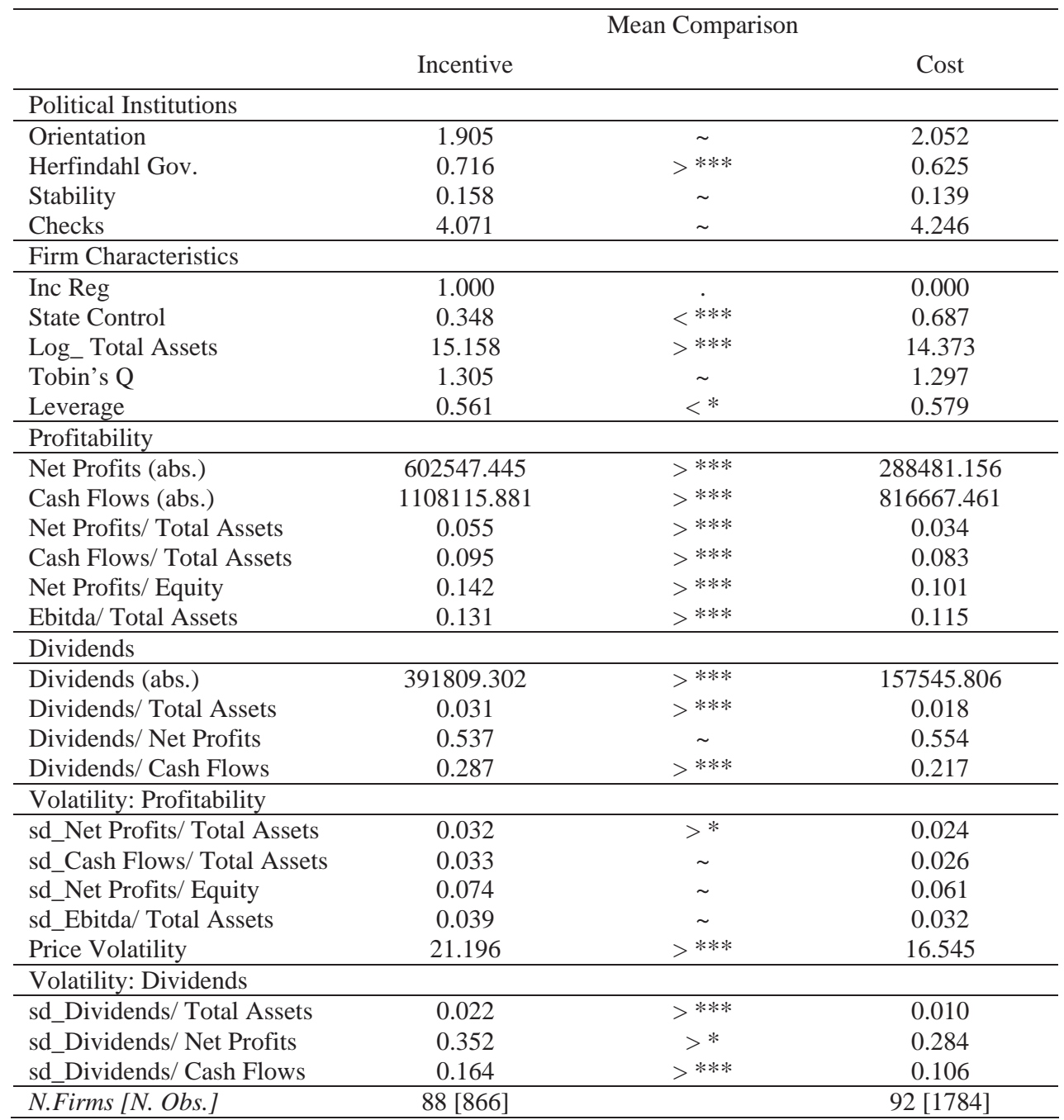

Note: ${ }^{*} p<0.1,{ }^{* *} p<0.05,{ }^{* * *} p<0.01$; The prefix sd inVolatility refers to the standard deviation of the single variables computed as firm averages; Mean difference tests in the section Political Institutions were computed on a nation-year basis. 
Table 3 - Main Results - Full Sample

\begin{tabular}{|c|c|c|c|}
\hline Dep. Var.: Dividends & OLS & FE & GMM \\
\hline Dividends $_{\mathrm{t}-1}$ & $\begin{array}{l}0.454^{* * *} \\
(0.129)\end{array}$ & $\begin{array}{l}0.379^{* * *} \\
(0.125)\end{array}$ & $\begin{array}{l}0.475^{* * *} \\
(0.119)\end{array}$ \\
\hline Net Profits & $\begin{array}{l}0.306^{* * *} \\
(0.0565)\end{array}$ & $\begin{array}{l}0.289^{* * *} \\
(0.0516)\end{array}$ & $\begin{array}{l}0.172^{* * *} \\
(0.0403)\end{array}$ \\
\hline $\begin{array}{l}\text { Instruments } 1 \\
\text { Standard } \\
\text { GMM-type }\end{array}$ & e equation & & $\begin{array}{l}\text { Dividends }{ }_{t-2} \\
\text { Net Profits }{ }_{t-1}\end{array}$ \\
\hline $\begin{array}{l}\text { Instrumer } \\
\text { Standard } \\
\text { GMM-type }\end{array}$ & uation & & $\begin{array}{l}\text { Constant } \\
\text { Dividends }{ }_{\mathrm{t}-1} \\
\text { Net Profits }\end{array}$ \\
\hline $\begin{array}{c}\text { N.Firms [N.Obs.] } \\
R^{2} \\
\text { adj. } R^{2} \\
\text { AIC } \\
\text { sarganp } \\
\text { hansenp } \\
\text { ar1p } \\
\text { ar2p } \\
\mathrm{j}\end{array}$ & $\begin{array}{c}106[1417] \\
0.736 \\
0.732 \\
40337.9\end{array}$ & $\begin{array}{c}106[1417] \\
0.604 \\
0.596 \\
40246.7\end{array}$ & $\begin{array}{c}\cdot \dot{0} \\
0.000 \\
0.117 \\
0.0107 \\
0.313 \\
94\end{array}$ \\
\hline
\end{tabular}

Standard errors in parentheses; ${ }^{*} p<0.1,{ }^{* *} p<0.05,{ }^{* * *} p<0.01$; hansenp represents the $\mathrm{p}$-value of the Hansen test of overid. restrictions; sarganp represents the p-value of the Sargan test of overid. restrictions; ar1p and ar2p represent the p-values of the autocorrelation tests of order 1 and 2 respectively; Note that year dummies were included in all presented specifications.

Table 3a: Smoothing (S), Impact (I) and Target Payout Ratio (Tpr)

\begin{tabular}{lccc}
\hline & OLS & FE & GMM \\
\hline $\mathrm{S}$ & $0.454^{* * *}$ & $0.379^{* * *}$ & $0.475^{* * *}$ \\
$\mathrm{I}$ & $0.306^{* * *}$ & $0.289^{* * *}$ & $0.172^{* * *}$ \\
$\mathrm{Tpr}$ & $0.560^{* * *}$ & $0.465^{* * *}$ & $0.327^{* * *}$ \\
\hline
\end{tabular}


Table 4: First Stage Regressions- Dependent Variable: Inc Reg

\begin{tabular}{|c|c|c|c|}
\hline & FE & Logit & $\begin{array}{l}\text { Logit } \\
\text { Sub-sample that switches } \\
\text { from Cost to Inc } \\
\end{array}$ \\
\hline Mean_State Control t-1 & $\begin{array}{c}-0.236^{* * * *} \\
(0.0823)\end{array}$ & $\begin{array}{c}-3.521^{* * *} \\
(0.426)\end{array}$ & $\begin{array}{c}-3.769^{* * *} \\
(1.033)\end{array}$ \\
\hline Herfindahl Gov. t-1 & $\begin{array}{l}0.0695 \\
(0.120)\end{array}$ & $\begin{array}{c}3.285^{* * *} \\
(0.835)\end{array}$ & $\begin{array}{c}0.375 \\
(1.188)\end{array}$ \\
\hline Checks ${ }_{t-1}$ & $\begin{array}{c}0.0332^{*} \\
(0.0177)\end{array}$ & $\begin{array}{l}-0.114 \\
(0.121)\end{array}$ & $\begin{array}{c}-0.321 \\
(0.215)\end{array}$ \\
\hline Orientation $_{\mathrm{t}-1}$ & $\begin{array}{c}-0.0508^{* * *} \\
(0.0192)\end{array}$ & $\begin{array}{l}-0.155 \\
(0.199)\end{array}$ & $\begin{array}{c}-0.528^{* *} \\
(0.232)\end{array}$ \\
\hline Stability $\mathrm{t}-1$ & $\begin{array}{l}-0.0340 \\
(0.0596)\end{array}$ & $\begin{array}{l}-0.231 \\
(0.609)\end{array}$ & $\begin{array}{l}-0.222 \\
(0.650)\end{array}$ \\
\hline $\begin{array}{l}N \\
R^{2} \\
\text { adj. } R^{2} \\
\text { AIC }\end{array}$ & $\begin{array}{c}380 \\
0.657 \\
0.612 \\
186.3 \\
\end{array}$ & 322.3 & 141.3 \\
\hline
\end{tabular}

Robust standard errors in parentheses, ${ }^{*} p<0.1,{ }^{* *} p<0.05,{ }^{* * *} p<0.01$ 
Table 5: The impact of incentive regulation

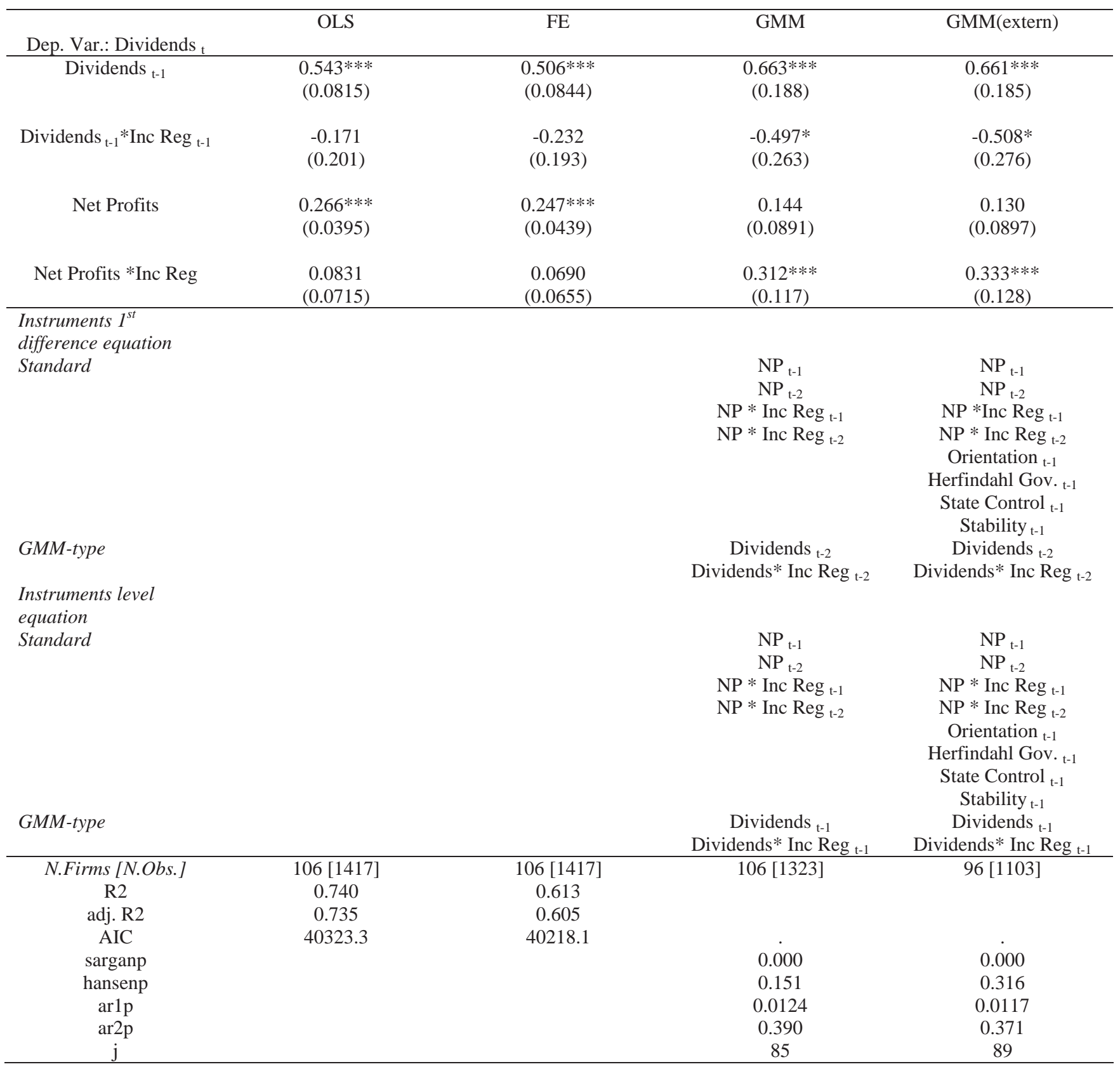

Standard errors in parentheses; ${ }^{*} p<0.1,{ }^{* *} p<0.05,{ }^{* * *} p<0.01$; hansenp represents the $\mathrm{p}$-value of the Hansen test of overid. restrictions; sarganp represents the p-value of the Sargan test of overid. restrictions; ar1p and ar2p represent the p-values of the autocorrelation tests of order 1 and 2 respectively; GMM refers to the "system GMM" and "extern" indicates the use of external instruments; Note that year dummies were included in all presented specifications.

Table 5a: Smoothing (S), Impact (I) and Target Payout Ratio (Tpr)

\begin{tabular}{l|cc|cc|cc|cc}
\hline & \multicolumn{2}{|c|}{ OLS } & \multicolumn{2}{c|}{ FE } & \multicolumn{2}{c|}{ GMM } & \multicolumn{2}{c}{ GMM(extern) } \\
\hline & Inc & Cost & Inc & Cost & Inc & Cost & Inc & Cost \\
\hline S & $0.372^{*}$ & $0.543^{* * *}$ & 0.273 & $0.506^{* * *}$ & 0.166 & $0.663^{* * *}$ & 0.152 & $0.661^{* * *}$ \\
$\mathrm{I}$ & $0.349^{* * *}$ & $0.266^{* * *}$ & $0.316^{* * *}$ & $0.247^{* * *}$ & $0.456^{* * *}$ & 0.144 & $0.464^{* * *}$ & 0.130 \\
$\mathrm{Tpr}$ & $0.555^{* * *}$ & $0.581^{* * *}$ & $0.435^{* * *}$ & $0.499^{* * *}$ & $0.547^{* * *}$ & $0.428^{* * *}$ & $0.547^{* * *}$ & $0.384^{* * * *}$ \\
\hline
\end{tabular}


Table 6: Profitability and dividend behaviour across regulation and control

\begin{tabular}{|c|c|c|c|c|c|c|}
\hline & \multicolumn{3}{|c|}{ Cost } & \multicolumn{3}{|c|}{ Incentive } \\
\hline & State & & Private & State & & Private \\
\hline \multicolumn{7}{|l|}{ Profitability } \\
\hline Net Profits/ Total Assets & $\begin{array}{c}0.035 \\
(0.037)\end{array}$ & $\sim$ & $\begin{array}{c}0.034 \\
(0.046)\end{array}$ & $\begin{array}{c}0.043 \\
(0.059)\end{array}$ & $<* * *$ & $\begin{array}{c}0.064 \\
(0.058)\end{array}$ \\
\hline Cash Flows/ Total Assets & $\begin{array}{c}0.086 \\
(0.042)\end{array}$ & $>* * *$ & $\begin{array}{c}0.078 \\
(0.050)\end{array}$ & $\begin{array}{c}0.085 \\
(0.062)\end{array}$ & $<* * *$ & $\begin{array}{c}0.102 \\
(0.060)\end{array}$ \\
\hline Net Profits/ Equity & $\begin{array}{c}0.101 \\
(0.089)\end{array}$ & $\sim$ & $\begin{array}{c}0.101 \\
(0.097)\end{array}$ & $\begin{array}{c}0.105 \\
(0.084)\end{array}$ & $<* * *$ & $\begin{array}{c}0.170 \\
(0.157)\end{array}$ \\
\hline Ebitda/ Total Assets & $\begin{array}{c}0.116 \\
(0.054)\end{array}$ & $\sim$ & $\begin{array}{c}0.113 \\
(0.055) \\
\end{array}$ & $\begin{array}{c}0.116 \\
(0.064) \\
\end{array}$ & $<* * *$ & $\begin{array}{c}0.142 \\
(0.071) \\
\end{array}$ \\
\hline \multicolumn{7}{|l|}{ Dividends } \\
\hline Dividends/ Total Assets & $\begin{array}{c}0.017 \\
(0.020)\end{array}$ & $<* * *$ & $\begin{array}{c}0.022 \\
(0.022)\end{array}$ & $\begin{array}{c}0.028 \\
(0.032)\end{array}$ & $\sim$ & $\begin{array}{c}0.033 \\
(0.043)\end{array}$ \\
\hline Dividends/ Net Profits & $\begin{array}{c}0.526 \\
(0.397)\end{array}$ & $<* * *$ & $\begin{array}{c}0.618 \\
(0.401)\end{array}$ & $\begin{array}{c}0.619 \\
(0.528)\end{array}$ & $>* * *$ & $\begin{array}{c}0.481 \\
(0.489)\end{array}$ \\
\hline Dividends/ Cash Flows & $\begin{array}{c}0.199 \\
(0.193)\end{array}$ & $<* * *$ & $\begin{array}{c}0.263 \\
(0.188) \\
\end{array}$ & $\begin{array}{c}0.301 \\
(0.226)\end{array}$ & $\sim$ & $\begin{array}{r}0.278 \\
(0.238) \\
\end{array}$ \\
\hline Price Volatility & $\begin{array}{l}17.219 \\
(6.329)\end{array}$ & $>*$ & $\begin{array}{l}16.145 \\
(6.996)\end{array}$ & $\begin{array}{l}21.951 \\
(5.570)\end{array}$ & $>* *$ & $\begin{array}{l}20.529 \\
(4.791)\end{array}$ \\
\hline
\end{tabular}

${ }^{*} p<0.1,{ }^{* *} p<0.05,{ }^{* * *} p<0.01$, Significance is reported according to mean difference tests on firm-year observations, Standard deviation in parentheses 
Table 7: The impact of regulation and control

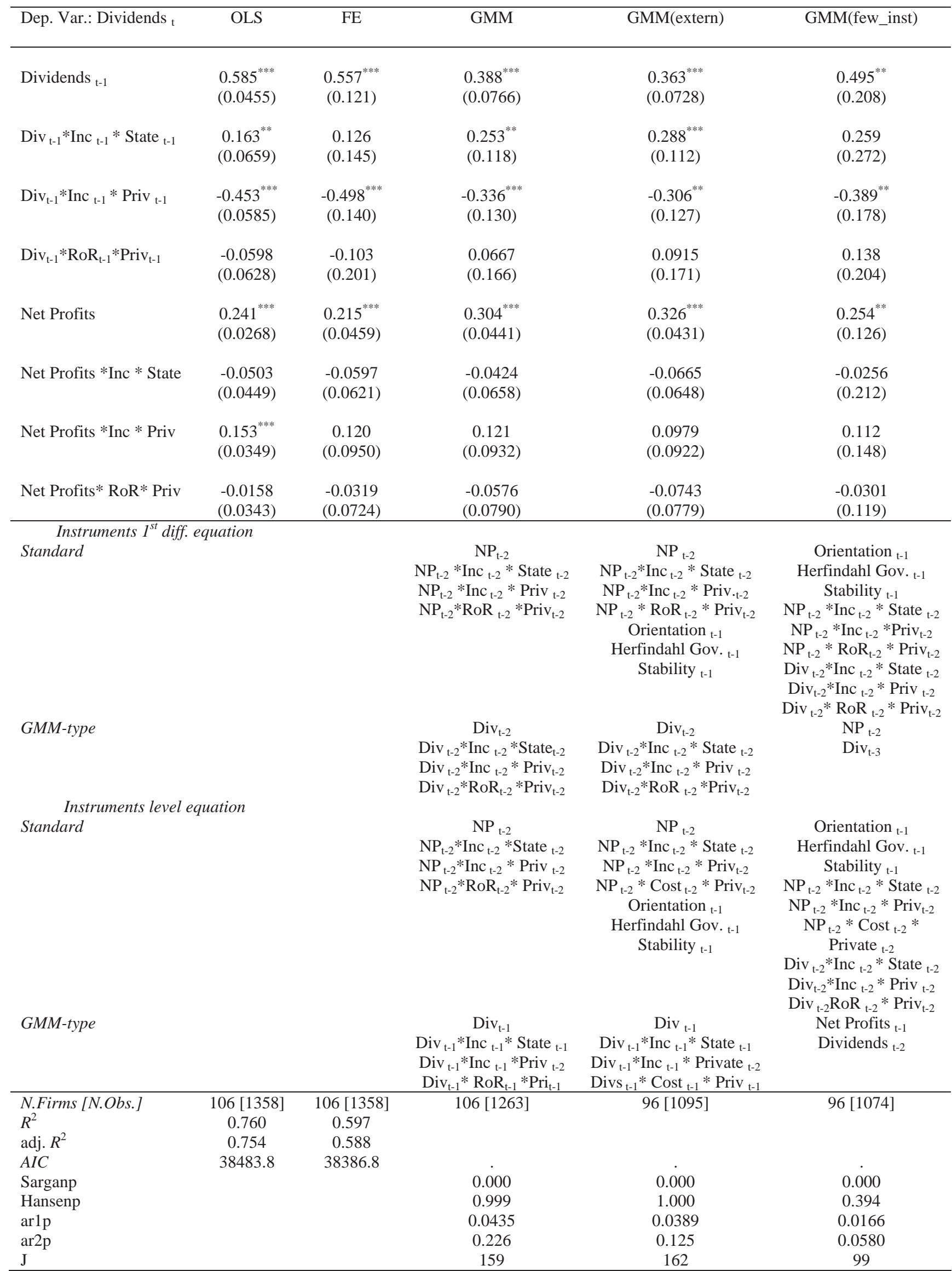

Standard errors in parentheses; ${ }^{*} p<0.1,{ }^{* *} p<0.05,{ }^{* * *} p<0.01$; hansenp represents the p-value of the Hansen test of overid. 
restrictions; sarganp represents the p-value of the Sargan test of overid. restrictions; ar1p and ar2p represent the p-values of the autocorrelation tests of order 1 and 2 respectively; GMM refers to the "system GMM", "extern" indicates the use of external instruments and "few_inst" the use of fewer instruments; "Dividends*Inc*State" refers to the interaction term between Dividends, a dummy indicating that Inc Reg is equal 1 and a dummy indicating that State Control is equal 1; "Dividends*Inc*Private" refers to the interaction term between Dividends, a dummy indicating that Inc Reg is equal 1 and a dummy indicating that State Control is equal 0; "Dividends* Cost *Private" refers to the interaction term between Dividends, a dummy indicating that Inc Reg is equal 0 and a dummy indicating that State Control is equal 0; "Net Profits*Inc*State" refers to the interaction term between Net Profits, a dummy indicating that Inc Reg is equal 1 and a dummy indicating that State Control is equal 1; "Net Profits*Inc*Private" refers to the interaction term between Net Profits, a dummy indicating that Inc Reg is equal 1 and a dummy indicating that State Control is equal 0; "Net Profits* Cost *Private" refers to the interaction term between Net Profits, a dummy indicating that Inc Reg is equal 0 and a dummy indicating that State Control is equal 0 ; Note that year dummies were included in all presented specifications.

Table 7a: Smoothing (S), Impact (I) and Target Payout Ratio (Tpr)

\begin{tabular}{|c|c|c|c|c|c|c|c|c|}
\hline & \multicolumn{4}{|c|}{ GMM } & \multicolumn{4}{|c|}{ GMM(extern) } \\
\hline & \multicolumn{2}{|c|}{ State } & \multicolumn{2}{|c|}{ Private } & \multicolumn{2}{|c|}{ State } & \multicolumn{2}{|c|}{ Private } \\
\hline & Inc & Cost & Inc & Cost & Inc & Cost & Inc & Cost \\
\hline $\mathrm{S}$ & $0.642 * * *$ & $0.388 * * *$ & 0.0524 & $0.455^{* * *}$ & $0.651^{* * *}$ & $0.363 * * *$ & 0.0571 & $0.455^{* * *}$ \\
\hline I & $0.261 * * *$ & $0.304 * * *$ & $0.425 * * *$ & $0.246 * * *$ & $0.260 * * *$ & $0.326 * * *$ & $0.424 * * *$ & $0.252 * * *$ \\
\hline \multirow[t]{7}{*}{$\mathrm{Tpr}$} & $0.729 * * *$ & $0.496 * * *$ & $0.448 * * *$ & $0.452^{* * *}$ & $0.745^{* * *}$ & $0.512^{* * *}$ & $0.450 * * *$ & $0.462 * * *$ \\
\hline & & & \multicolumn{4}{|c|}{ GMM(few_inst) } & & \\
\hline & & & \multicolumn{2}{|c|}{ State } & \multicolumn{2}{|c|}{ Private } & & \\
\hline & & & Inc & Cost & Inc & Cost & & \\
\hline & & $S$ & $0.754 * * *$ & $0.495^{* *}$ & 0.106 & $0.633^{* * *}$ & & \\
\hline & & I & $0.229 * *$ & $0.254 * *$ & $0.366^{* *}$ & $0.224 * * *$ & & \\
\hline & & Tpr & $0.930 * * *$ & $0.504^{* * *}$ & $0.410 * * *$ & $0.612^{* * *}$ & & \\
\hline
\end{tabular}




\section{Appendix}

Table A1: - Panel Structure

\begin{tabular}{lccc}
\hline $\begin{array}{l}\text { Available } \\
\text { Observations }\end{array}$ & Number of Firms & $\%$ & Cumm. \% \\
\hline 6 & 4 & 3.77 & 3.77 \\
7 & 12 & 11.32 & 15.09 \\
8 & 6 & 5.66 & 20.75 \\
9 & 7 & 6.60 & 27.36 \\
10 & 5 & 4.72 & 32.08 \\
11 & 12 & 11.32 & 43.40 \\
12 & 3 & 2.83 & 46.23 \\
13 & 4 & 3.77 & 50.00 \\
14 & 3 & 2.83 & 52.83 \\
15 & 11 & 10.38 & 63.21 \\
16 & 4 & 3.77 & 66.98 \\
17 & 2 & 1.89 & 68.87 \\
18 & 2 & 1.89 & 70.75 \\
19 & 2 & 1.89 & 72.64 \\
20 & 5 & 4.72 & 77.36 \\
21 & 3 & 2.83 & 80.19 \\
22 & 2 & 1.89 & 82.08 \\
23 & 5 & 4.72 & 86.79 \\
24 & 3 & 2.83 & 89.62 \\
25 & 11 & 10.38 & 100.00 \\
\hline$N$ & 106 & & \\
\hline
\end{tabular}

Table A2: Dividend Payout Ratios (Descriptive Statistics for Nations)

\begin{tabular}{lccccc}
\hline Nation & Firms & Observations & Mean & Median & Std. Deviation \\
\hline Austria & 4 & 79 & $54.72 \%$ & $38.95 \%$ & $39.47 \%$ \\
Belgium & 4 & 56 & $67.82 \%$ & $74.68 \%$ & $32.45 \%$ \\
Czech Republic & 12 & 107 & $34.05 \%$ & $24.68 \%$ & $42.97 \%$ \\
Denmark & 2 & 25 & $38.52 \%$ & $34.26 \%$ & $28.70 \%$ \\
Finland & 3 & 50 & $58.62 \%$ & $40.22 \%$ & $55.10 \%$ \\
France & 5 & 100 & $33.05 \%$ & $30.65 \%$ & $35.34 \%$ \\
Germany & 22 & 305 & $67.10 \%$ & $63.96 \%$ & $37.13 \%$ \\
Greece & 1 & 10 & $44.60 \%$ & $29.22 \%$ & $47.80 \%$ \\
Hungary & 3 & 28 & $61.58 \%$ & $80.08 \%$ & $61.47 \%$ \\
Italy & 9 & 112 & $63.51 \%$ & $57.28 \%$ & $60.73 \%$ \\
Luxembourg & 1 & 20 & $62.02 \%$ & $67.51 \%$ & $15.39 \%$ \\
Norway & 3 & 49 & $33.61 \%$ & $24.12 \%$ & $39.00 \%$ \\
Portugal & 2 & 22 & $70.00 \%$ & $67.58 \%$ & $25.99 \%$ \\
Spain & 8 & 137 & $59.92 \%$ & $56.64 \%$ & $31.91 \%$ \\
Sweden & 35 & $55.51 \%$ & $43.85 \%$ & $32.05 \%$ \\
Switzerland & 10 & 188 & $58.96 \%$ & $52.33 \%$ & $38.56 \%$ \\
UK & 14 & 159 & $43.79 \%$ & $32.62 \%$ & $50.28 \%$ \\
\hline Total & 106 & 1,482 & $54.86 \%$ & $49.63 \%$ & $43.35 \%$ \\
\hline
\end{tabular}

Note: Presented data refer to the variable Dividend Payout Ratio. 
Table A3 - First Stage Analysis: Pairwise correlations

\begin{tabular}{c|cccccc}
\hline & Reg Inc & $\begin{array}{c}\text { Mean_State } \\
\text { Control }\end{array}$ & $\begin{array}{c}\text { Herfindahl } \\
\text { Gov. }\end{array}$ & Checks & Orientation & \\
\hline Reg Inc & 1 & & & & \\
Mean_State Control & $-0.395^{* * *}$ & 1 & & & \\
Herfindahl Gov. & $0.172^{* * *}$ & $0.167^{* * *}$ & 1 & & \\
Checks & -0.061 & $-0.162^{* * *}$ & $-0.386^{* * *}$ & 1 & & \\
Orientation & -0.071 & $0.176^{* * *}$ & $0.307^{* * *}$ & $-0.188^{* * *}$ & 1 & 1 \\
Stability & -0.012 & 0.043 & $0.092^{*}$ & -0.029 & 0.002 & 1 \\
\hline
\end{tabular}




\section{Cash flow results}

Table A4: Main Results - Full Sample Cash Flows

\begin{tabular}{|c|c|c|c|}
\hline Dep. Var.: Dividends ${ }_{t}$ & OLS & FE & GMM \\
\hline Dividends ${ }_{t-1}$ & $\begin{array}{l}0.507^{* * *} \\
(0.141)\end{array}$ & $\begin{array}{l}0.316^{* *} \\
(0.134)\end{array}$ & $\begin{array}{l}0.395^{* * *} \\
(0.132)\end{array}$ \\
\hline Cash Flows & $\begin{array}{l}0.140^{* * *} \\
(0.0439)\end{array}$ & $\begin{array}{l}0.236^{* * *} \\
(0.0427)\end{array}$ & $\begin{array}{c}0.117^{* * *} \\
(0.0260)\end{array}$ \\
\hline $\begin{array}{l}\text { Instruments } 1^{\text {st }} \text { c } \\
\text { Standard } \\
\text { GMM-type } \\
\text { Instruments } \\
\text { Standard } \\
\text { GMM-type }\end{array}$ & equation & & $\begin{array}{l}\text { Dividends } \mathrm{t}_{\mathrm{t}-2} \\
\text { Cash Flows }{ }_{\mathrm{t}-1} \\
\text { Constant } \\
\text { Dividends }{ }_{\mathrm{t}-1} \\
\text { Cash Flows }\end{array}$ \\
\hline $\begin{array}{l}\text { N.Firms [N.Obs.] } \\
R^{2} \\
\text { adj. } R^{2} \\
\text { AIC } \\
\text { sarganp } \\
\text { hansenp } \\
\text { ar1p } \\
\text { ar2p } \\
\mathrm{j}\end{array}$ & $\begin{array}{c}106[1413] \\
0.728 \\
0.723 \\
40270.9\end{array}$ & $\begin{array}{c}106[1413] \\
0.626 \\
0.619 \\
40055.3\end{array}$ & $\begin{array}{c}0 . \\
0.000 \\
0.0852 \\
0.0128 \\
0.342 \\
94 \\
\end{array}$ \\
\hline
\end{tabular}

Standard errors in parentheses; ${ }^{*} p<0.1,{ }^{* *} p<0.05,{ }^{* * *} p<0.01$; hansenp represents the p-value of the Hansen test of overid. restrictions; sarganp represents the p-value of the Sargan test of overid. restrictions; ar1p and ar2p represent the p-values of the autocorrelation tests of order 1 and 2 respectively; Note that year dummies were included in all presented specifications.

Table A4a: Smoothing (S), Impact (I) and Tpr - Cash Flows

\begin{tabular}{lccc}
\hline & OLS & FE & GMM \\
\hline $\mathrm{S}$ & $0.507^{* * *}$ & $0.316^{* *}$ & $0.395^{* * *}$ \\
$\mathrm{I}$ & $0.140^{* * *}$ & $0.236^{* * *}$ & $0.117^{* * *}$ \\
$\mathrm{Tpr}$ & $0.283^{* * *}$ & $0.346^{* * *}$ & $0.193^{* * *}$ \\
\hline
\end{tabular}


Table A5: The impact of incentive regulation - Cash Flows

\begin{tabular}{|c|c|c|c|c|}
\hline Dep. Var.: Dividends ${ }_{t}$ & OLS & FE & GMM & GMM(extern) \\
\hline Dividends ${ }_{t-1}$ & $\begin{array}{l}0.580^{* * *} \\
(0.107)\end{array}$ & $\begin{array}{l}0.408^{* * *} \\
(0.0699)\end{array}$ & $\begin{array}{l}0.555^{* * *} \\
(0.211)\end{array}$ & $\begin{array}{l}0.521^{* *} \\
(0.212)\end{array}$ \\
\hline Dividends* Inc Reg $\mathrm{t}-1$ & $\begin{array}{l}-0.262 \\
(0.199)\end{array}$ & $\begin{array}{l}-0.180 \\
(0.167)\end{array}$ & $\begin{array}{l}-0.469^{* *} \\
(0.230)\end{array}$ & $\begin{array}{l}-0.456^{*} \\
(0.237)\end{array}$ \\
\hline Cash Flows & $\begin{array}{l}0.113^{* * *} \\
(0.0317)\end{array}$ & $\begin{array}{l}0.207^{* * *} \\
(0.0276)\end{array}$ & $\begin{array}{l}0.0907^{* *} \\
(0.0442)\end{array}$ & $\begin{array}{l}0.0976^{* *} \\
(0.0474)\end{array}$ \\
\hline Cash Flows* Inc Reg & $\begin{array}{c}0.113^{* *} \\
(0.0565)\end{array}$ & $\begin{array}{c}0.0546 \\
(0.0403)\end{array}$ & $\begin{array}{l}0.195^{* * *} \\
(0.0602)\end{array}$ & $\begin{array}{l}0.206^{* * *} \\
(0.0610)\end{array}$ \\
\hline \multicolumn{5}{|l|}{$\begin{array}{l}\text { Instruments } 1^{\text {st }} \\
\text { difference equation }\end{array}$} \\
\hline Standard & & & $\begin{array}{c}\text { Cash Flows }{ }_{\mathrm{t}-1} \\
\text { Cash Flows }_{\mathrm{t}-2} \\
\text { Cash Flows * Inc Reg }{ }_{\mathrm{t}-1} \\
\text { Cash Flows * Inc Reg } \mathrm{t}_{\mathrm{t}-2}\end{array}$ & $\begin{array}{c}\text { Cash Flows } \mathrm{t}_{-1} \\
\text { Cash Flows }_{\mathrm{t}-2} \\
\text { Cash Flows * Inc Reg } \mathrm{t}_{\mathrm{t}-1} \\
\text { Cash Flows *Inc Reg } \mathrm{t}-2 \\
\text { Orientation }_{\mathrm{t}-1} \\
\text { Herfindahl Gov. } \mathrm{t}-1 \\
\text { State Control } \mathrm{t}-1\end{array}$ \\
\hline GMM-type & & & $\begin{array}{l}\text { Dividends }{ }_{\mathrm{t}-2} \\
\text { Dividends*Inc Reg t-2 }\end{array}$ & $\begin{array}{l}\text { Dividends }{ }_{\mathrm{t}-2} \\
\text { Dividends*Inc Reg t-2 }\end{array}$ \\
\hline \multicolumn{5}{|l|}{$\begin{array}{l}\text { Instruments level } \\
\text { equation }\end{array}$} \\
\hline Standard & & & $\begin{array}{c}\text { Cash Flows }{ }_{\mathrm{t}-1} \\
\text { Cash Flows } \mathrm{t}-2 \\
\text { Cash Flows *Inc Reg } \text { t }-1^{2} \\
\text { Cash Flows *Inc Reg } \mathrm{t}_{-2}\end{array}$ & $\begin{array}{c}\text { Cash Flows }_{\mathrm{t}-1} \\
\text { Cash Flows }_{\mathrm{t}-2} \\
\text { Cash Flows *Inc Reg } \mathrm{t}-1 \\
{\text { Cash Flows } \text { Inc Reg }_{\mathrm{t}-2}} \\
\text { Orientation }_{\mathrm{t}-1} \\
\text { Herfindahl Gov. } \mathrm{t}-1 \\
\text { State Control }_{\mathrm{t}-1}\end{array}$ \\
\hline GMM-type & & & $\begin{array}{l}\text { Dividends }{ }_{\mathrm{t}-1} \\
\text { Dividends*Inc Reg }_{\mathrm{t}-1}\end{array}$ & $\begin{array}{l}\text { Dividends }{ }_{\mathrm{t}-1} \\
\text { Dividends*Inc Reg } \mathrm{t}-1\end{array}$ \\
\hline N.Firms [N.Obs.] & 106 [1413] & 106 [1413] & $106[1314]$ & 96 [1094] \\
\hline $\begin{array}{l}R^{2} \\
\text { adj. } R^{2}\end{array}$ & $\begin{array}{l}0.742 \\
0.737\end{array}$ & $\begin{array}{l}0.632 \\
0.625\end{array}$ & & \\
\hline$A I C$ & 40201.1 & 40036.9 & . & \\
\hline sarganp & & & 0.000 & 0.000 \\
\hline hansenp & & & 0.158 & 0.231 \\
\hline ar1p & & & 0.00775 & 0.00739 \\
\hline ar2p & & & 0.395 & 0.394 \\
\hline j & & & 85 & 89 \\
\hline
\end{tabular}

Standard errors in parentheses; ${ }^{*} p<0.1,{ }^{* *} p<0.05,{ }^{* * *} p<0.01$; hansenp represents the p-value of the Hansen test of overid. restrictions; sarganp represents the p-value of the Sargan test of overid. restrictions; ar1p and ar2p represent the p-values of the autocorrelation tests of order 1 and 2 respectively; GMM refers to the "system GMM" and "extern" indicates the use of external instruments. Year dummies were included in all presented specifications.

Table A5a: Smoothing (S), Impact (I) and Target Payout Ratio (Tpr) - Cash Flows

\begin{tabular}{l|cc|cc|cc|cc}
\hline & \multicolumn{2}{|c|}{ OLS } & \multicolumn{2}{c|}{ FE } & \multicolumn{2}{c|}{ GMM } & \multicolumn{2}{c}{ GMM(extern) } \\
\hline & Inc & Cost & Inc & Cost & Inc & Cost & Inc & Cost \\
\hline $\mathrm{S}$ & $0.318^{*}$ & $0.580^{* * *}$ & 0.228 & $0.408^{* * *}$ & 0.0858 & $0.555^{* * *}$ & 0.0651 & $0.521^{* *}$ \\
$\mathrm{I}$ & $0.226^{* * *}$ & $0.113^{* * *}$ & $0.261^{* * *}$ & $0.207^{* * *}$ & $0.286^{* * *}$ & $0.0907^{* *}$ & $0.303^{* * *}$ & $0.0976^{* *}$ \\
$\mathrm{Tpr}$ & $0.331^{* * *}$ & $0.269^{* * *}$ & $0.338^{* * *}$ & $0.349^{* * *}$ & $0.313^{* * *}$ & $0.204^{* * *}$ & $0.324^{* * *}$ & $0.204^{* * *}$ \\
\hline
\end{tabular}


Table A6: The impact of regulation and control - Cash Flows

\begin{tabular}{|c|c|c|c|c|c|}
\hline Dep. Var.: Dividends ${ }_{t}$ & OLS & $\mathrm{FE}$ & GMM & GMM(extern) & GMM(few_inst) \\
\hline Dividends ${ }_{t-1}$ & $\begin{array}{l}0.664^{* * *} \\
(0.0409)\end{array}$ & $\begin{array}{l}0.505^{* * *} \\
(0.0921)\end{array}$ & $\begin{array}{l}0.348^{* * *} \\
(0.0918)\end{array}$ & $\begin{array}{l}0.343^{* * *} \\
(0.0868)\end{array}$ & $\begin{array}{l}0.541^{* * *} \\
(0.143)\end{array}$ \\
\hline Dividends $_{\mathrm{t}-1} * \mathrm{Inc}_{\mathrm{t}-1} *$ State $_{\mathrm{t}-1}$ & $\begin{array}{c}0.0419 \\
(0.0613)\end{array}$ & $\begin{array}{c}0.146 \\
(0.113)\end{array}$ & $\begin{array}{l}0.199^{*} \\
(0.119)\end{array}$ & $\begin{array}{c}0.234^{*} \\
(0.123)\end{array}$ & $\begin{array}{l}-0.0406 \\
(0.280)\end{array}$ \\
\hline Dividends $_{\mathrm{t}-1} * \operatorname{Inc}_{\mathrm{t}-1} *$ Private $_{\mathrm{t}-1}$ & $\begin{array}{l}-0.617^{* * *} \\
(0.0549)\end{array}$ & $\begin{array}{c}-0.511^{* * *} \\
(0.108)\end{array}$ & $\begin{array}{c}-0.393^{* * *} \\
(0.132)\end{array}$ & $\begin{array}{c}-0.413^{* * *} \\
(0.120)\end{array}$ & $\begin{array}{c}-0.623^{* * *} \\
(0.209)\end{array}$ \\
\hline Dividends $_{\mathrm{t}-1} *$ Cost $_{\mathrm{t}-1} *$ Private $_{\mathrm{t}-1}$ & $\begin{array}{l}-0.363^{* * *} \\
(0.0621)\end{array}$ & $\begin{array}{l}-0.197 \\
(0.172)\end{array}$ & $\begin{array}{l}-0.175 \\
(0.169)\end{array}$ & $\begin{array}{l}-0.238 \\
(0.162)\end{array}$ & $\begin{array}{l}-0.305 \\
(0.247)\end{array}$ \\
\hline Cash Flows & $\begin{array}{l}0.0699^{* * *} \\
(0.00882)\end{array}$ & $\begin{array}{l}0.146^{* * *} \\
(0.0213)\end{array}$ & $\begin{array}{l}0.106^{* * *} \\
(0.0204)\end{array}$ & $\begin{array}{l}0.106^{* * *} \\
(0.0194)\end{array}$ & $\begin{array}{l}0.0708^{* *} \\
(0.0277)\end{array}$ \\
\hline Cash Flows $*$ Inc $*$ State & $\begin{array}{l}0.0495^{* *} \\
(0.0208)\end{array}$ & $\begin{array}{l}-0.00598 \\
(0.0243)\end{array}$ & $\begin{array}{l}0.0781^{* * *} \\
(0.0263)\end{array}$ & $\begin{array}{l}0.0649^{* *} \\
(0.0275)\end{array}$ & $\begin{array}{c}0.149 \\
(0.141)\end{array}$ \\
\hline Cash Flows $*$ Inc $*$ Private & $\begin{array}{l}0.222^{* * *} \\
(0.0171)\end{array}$ & $\begin{array}{l}0.142^{* * *} \\
(0.0528)\end{array}$ & $\begin{array}{l}0.222^{* * *} \\
(0.0525)\end{array}$ & $\begin{array}{l}0.236^{* * *} \\
(0.0456)\end{array}$ & $\begin{array}{l}0.271^{* * *} \\
(0.0884)\end{array}$ \\
\hline Cash Flows $*$ Cost $*$ Private & $\begin{array}{l}0.134^{* * *} \\
(0.0166)\end{array}$ & $\begin{array}{l}0.0836^{*} \\
(0.0497)\end{array}$ & $\begin{array}{l}0.137^{* * *} \\
(0.0394)\end{array}$ & $\begin{array}{l}0.159^{* * *} \\
(0.0342)\end{array}$ & $\begin{array}{l}0.184^{* * *} \\
(0.0650)\end{array}$ \\
\hline \multicolumn{6}{|c|}{ Instruments $1^{\text {st }}$ difference equation } \\
\hline GMM-type & & & $\begin{array}{c}\operatorname{Div}_{\mathrm{t}-2} \\
\operatorname{Div}_{\mathrm{t}-2} * \operatorname{Inc}_{\mathrm{t}-2} * \text { State }_{-2} \\
\operatorname{Div}_{\mathrm{t}-2} * \operatorname{Inc}_{\mathrm{t}-2} * \operatorname{Priv}_{\mathrm{t}-2} \\
\operatorname{Div}_{\mathrm{t}-2} * \text { Cost }_{\mathrm{t}-2} * \\
\operatorname{Priv}_{\mathrm{t}-2}\end{array}$ & $\begin{array}{c}\text { CF }_{\mathrm{t}-2} \\
\mathrm{CF}_{\mathrm{t}-2} * \text { Inc }_{\mathrm{t}-2} * \text { State }_{\mathrm{t}-2} \\
\mathrm{CF}_{\mathrm{t}-2} * \mathrm{Inc}_{\mathrm{t}-2} * \text { Priv }_{\mathrm{t}-2} \\
\mathrm{CF}_{\mathrm{t}-2} * \operatorname{Cost}_{\mathrm{t}-2} * \text { Priv }_{\mathrm{t}-2} \\
\text { Orientation } \\
\text { Herfindahl Gov.t-1 } \\
\text { Stability } \mathrm{t}-1 \\
\\
\text { Div }_{\mathrm{t}-2} \\
\text { Div }_{\mathrm{t}-2} * \operatorname{Inc}_{\mathrm{t}-2} * \text { State }_{\mathrm{t}-2} \\
\text { Div }_{\mathrm{t}-2} * \operatorname{Inc}_{\mathrm{t}-2} * \text { Priv }_{\mathrm{t}-2} \\
\text { Div }_{\mathrm{t}-2} * \operatorname{Cost}_{\mathrm{t}-2} * \text { Priv }_{\mathrm{t}-2}\end{array}$ & 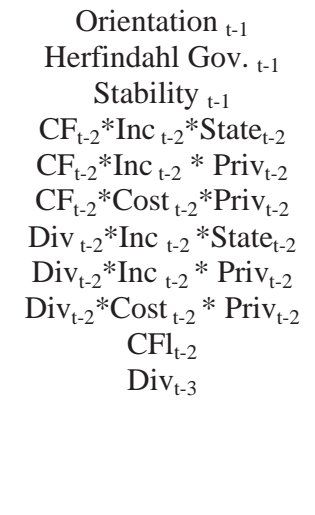 \\
\hline $\begin{array}{l}\text { Instruments level equation } \\
\text { Standard }\end{array}$ & & & $\begin{array}{c}\mathrm{CF}_{\mathrm{t}-2} \\
\mathrm{CF}_{\mathrm{t}-2} * \operatorname{Inc}_{\mathrm{t}-2} * \text { State }_{\mathrm{t}-2} \\
\mathrm{CF}_{\mathrm{t}-2} * \operatorname{Inc}_{\mathrm{t}-2} * \text { Priv }_{\mathrm{t}-2} \\
\mathrm{CF}_{\mathrm{t}-2} * \operatorname{RoR}_{\mathrm{t}-2} * \text { Priv }_{\mathrm{t}-2}\end{array}$ & $\begin{array}{c}\mathrm{CF}_{\mathrm{t}-2} \\
\mathrm{CF}_{\mathrm{t}-2} * \text { Inc }_{\mathrm{t}-2} * \text { State }_{\mathrm{t}-2} \\
\mathrm{CF}_{\mathrm{t}-2} * \mathrm{Inc}_{\mathrm{t}-2} * \text { Priv }_{\mathrm{t}-2} \\
\mathrm{CF}_{\mathrm{t}-2} * \operatorname{RoR}_{\mathrm{t}-2} * \text { Priv }_{\mathrm{t}-2} \\
\text { Orientation } \\
\text { Herfindahl Gov } \\
\text { Stability } \\
\\
\\
\text { Div }_{\mathrm{t}-1} \\
\text { Div }_{\mathrm{t}-1} * \operatorname{Inc}_{\mathrm{t}-1} * \text { State }_{\mathrm{t}-1} \\
\operatorname{Div}_{\mathrm{t}-1} * \operatorname{Inc}_{\mathrm{t}-1} * \text { Priv }_{\mathrm{t}-2} \\
\operatorname{Div}_{\mathrm{t}-1} * \operatorname{RoR}_{\mathrm{t}-1} * \text { Priv }_{\mathrm{t}-1}\end{array}$ & $\begin{array}{c}\text { Orientation } \mathrm{t}-1 \\
\text { Herfindahl Gov. } \mathrm{t}-1 \\
\text { Stability }{ }_{\mathrm{t}-1} \\
\mathrm{CF}_{\mathrm{t}-2} * \mathrm{Inc}_{\mathrm{t}-2} * \text { State }_{\mathrm{t}-2} \\
\mathrm{CF}_{\mathrm{t}-2} * \mathrm{Inc}_{\mathrm{t}-2} * \text { Private }_{\mathrm{t}-2} \\
\mathrm{CF}_{\mathrm{t}-2} * \text { Ror }_{\mathrm{t}-2} * \text { Priv }_{\mathrm{t}-2} \\
\text { Div }_{\mathrm{t}-2} * \text { Inc }_{\mathrm{t}-2} * \text { State }_{\mathrm{t}-2} \\
\text { Div }_{\mathrm{t}-2} * \mathrm{Inc}_{\mathrm{t}-2} * \text { Priv }_{\mathrm{t}-2} \\
\text { Div }_{\mathrm{t}-2} * \operatorname{Ror}_{\mathrm{t}-2} * \operatorname{Priv}_{\mathrm{t}-2} \\
\text { CF }_{\mathrm{t}-1} \\
\text { Div }_{\mathrm{t}-2}\end{array}$ \\
\hline N.Firms [N.Obs.] & $106[1354]$ & $106[1354]$ & $106[1255]$ & $96[1087]$ & 96 [1068] \\
\hline $\begin{array}{l}R^{2} \\
\text { adj. } R^{2}\end{array}$ & $\begin{array}{c}0.774 \\
0.768 \\
382957\end{array}$ & $\begin{array}{c}0.618 \\
0.609 \\
382061\end{array}$ & & & \\
\hline $\begin{array}{l}\text { AIC } \\
\text { sarganp }\end{array}$ & 38295.7 & 38206.1 & 0.000 & 0.000 & 0.000 \\
\hline hansenp & & & 0.997 & 1.000 & 0.195 \\
\hline ar1p & & & 0.0396 & 0.0520 & 0.0297 \\
\hline $\operatorname{ar} 2 p$ & & & 0.146 & 0.180 & 0.300 \\
\hline $\mathrm{J}$ & & & 159 & 162 & 99 \\
\hline
\end{tabular}

Standard errors in parentheses; ${ }^{*} p<0.1,{ }^{* *} p<0.05,{ }^{* * *} p<0.01$; hansenp represents the $\mathrm{p}$-value of the Hansen test of overid. restrictions; sarganp represents the p-value of the Sargan test of overid. restrictions; ar1p and ar2p represent the p-values of 
the autocorrelation tests of order 1 and 2 respectively; GMM refers to the "system GMM", "extern” indicates the use of external instruments and "few_inst" the use of fewer instruments; "Dividends*Inc*State" refers to the interaction term between Dividends, a dummy indicating that Inc Reg is equal 1 and a dummy indicating that State Control is equal 1; "Dividends*Inc*Private" refers to the interaction term between Dividends, a dummy indicating that Inc Reg is equal 1 and a dummy indicating that State Control is equal 0; "Dividends* Cost *Private" refers to the interaction term between Dividends, a dummy indicating that Inc Reg is equal 0 and a dummy indicating that State Control is equal 0; "Cash Flows *Inc*State" refers to the interaction term between Cash Flows, a dummy indicating that Inc Reg is equal 1 and a dummy indicating that State Control is equal 1; "Cash Flows *Inc*Private" refers to the interaction term between Cash Flows, a dummy indicating that Inc Reg is equal 1 and a dummy indicating that State Control is equal 0; "Cash Flows * Cost *Private" refers to the interaction term between Cash Flows, a dummy indicating that Inc Reg is equal 0 and a dummy indicating that State Control is equal 0; Note that year dummies were included in all presented specifications.

Table A6a: Smoothing (S), Impact (I) and Target Payout Ratio (Tpr) - Cash Flows

\begin{tabular}{c|cccc|cccc|}
\hline & \multicolumn{4}{|c|}{ GMM } & \multicolumn{3}{c}{ GMM(extern) } \\
\hline & \multicolumn{2}{|c|}{ State } & \multicolumn{2}{c|}{ Private } & \multicolumn{2}{c|}{ State } & \multicolumn{3}{c|}{ Private } \\
\hline & Inc & Cost & Inc & Cost & Inc & Cost & Inc & Cost \\
\hline S & $0.547^{* * *}$ & $0.348^{* * *}$ & - & 0.172 & $0.577^{* * *}$ & $0.343^{* * *}$ & - & 0.104 \\
$\mathrm{I}$ & $0.184^{* * *}$ & $0.106^{* * *}$ & $0.327^{* * *}$ & $0.243^{* * *}$ & $0.171^{* * *}$ & $0.106^{* * *}$ & $0.342^{* * *}$ & $0.265^{* * *}$ \\
$\mathrm{Tpr}$ & $0.405^{* * *}$ & $0.162^{* * *}$ & $0.313^{* * *}$ & $0.294^{* * *}$ & $0.404^{* * *}$ & $0.161^{* * *}$ & $0.320^{* * *}$ & $0.296^{* * *}$ \\
\hline
\end{tabular}

\begin{tabular}{c|cccc}
\hline & \multicolumn{4}{|c}{ GMM(few_inst) } \\
\hline & \multicolumn{3}{|c}{ State } & \multicolumn{2}{c}{ Private } \\
\hline & Inc & Cost & Inc & Cost \\
\hline S & $0.500^{*}$ & $0.541^{* * *}$ & - & 0.236 \\
$\mathrm{I}$ & $0.220^{*}$ & $0.0708^{* *}$ & $0.342^{* * *}$ & $0.255^{* * *}$ \\
$\mathrm{Tpr}$ & $0.441^{* * *}$ & $0.154^{* * *}$ & $0.316^{* * *}$ & $0.333^{* * *}$ \\
\hline
\end{tabular}


Table A7: Incentive vs Cost-Based Regulation - Analysis by sub-sampling

\begin{tabular}{|c|c|c|c|c|c|c|}
\hline \multirow{2}{*}{ Dep. Var.: Dividends ${ }_{\mathrm{t}}$} & \multicolumn{2}{|c|}{ OLS } & \multicolumn{2}{|c|}{ FE } & \multicolumn{2}{|c|}{ GMM } \\
\hline & Inc & Cost & Inc & Cost & Inc & Cost \\
\hline Dividends $\mathrm{t}-1$ & $\begin{array}{c}0.303 \\
(0.181)\end{array}$ & $\begin{array}{l}0.644^{* * * *} \\
(0.0967)\end{array}$ & $\begin{array}{l}0.0558 \\
(0.101)\end{array}$ & $\begin{array}{l}0.610^{* * *} \\
(0.0917)\end{array}$ & $\begin{array}{l}0.446^{*} \\
(0.268)\end{array}$ & $\begin{array}{l}0.761^{* * *} \\
(0.123)\end{array}$ \\
\hline Net Profits ${ }_{t-3}$ & $\begin{array}{l}0.403^{* * * *} \\
(0.0657)\end{array}$ & $\begin{array}{l}0.234^{* * *} \\
(0.0435)\end{array}$ & $\begin{array}{l}0.285^{* * *} \\
(0.0458)\end{array}$ & $\begin{array}{l}0.233^{* * * *} \\
(0.0523)\end{array}$ & $\begin{array}{c}0.377^{* * *} \\
(0.135)\end{array}$ & $\begin{array}{c}0.115^{*} \\
(0.0592)\end{array}$ \\
\hline $\begin{array}{l}\quad \text { Instruments } 1^{\text {st }} \text { diff } \\
\text { Standard } \\
\text { GMM-type }\end{array}$ & equation & & & & $\begin{array}{l}\text { Dividends }{ }_{t-3} \\
\text { Net Profits }{ }_{t-3}\end{array}$ & $\begin{array}{l}\text { Dividends }{ }_{t-3} \\
\text { Net Profits }{ }_{t-2}\end{array}$ \\
\hline $\begin{array}{l}\quad \text { Instruments le } \\
\text { Standard } \\
\text { GMM-type }\end{array}$ & Iation & & & & $\begin{array}{c}\text { Constant } \\
\text { Dividends } \mathrm{t}_{\mathrm{t}-2} \\
\text { Net Profits } \mathrm{t}-2 \\
\end{array}$ & $\begin{array}{l}\text { Constant } \\
\text { Dividends } \mathrm{t}_{-2} \\
\text { Net Profits } \mathrm{t}-2\end{array}$ \\
\hline $\begin{array}{l}\text { N.Firms [N. Obs.] } \\
R^{2} \\
\text { adj. } R^{2} \\
\text { AIC } \\
\text { sarganp } \\
\text { hansenp } \\
\text { ar1p } \\
\text { ar2p } \\
\text { j }\end{array}$ & $\begin{array}{c}65[443] \\
0.678 \\
0.661 \\
12933.0\end{array}$ & $\begin{array}{c}85[974] \\
0.819 \\
0.815 \\
27025.6\end{array}$ & $\begin{array}{c}65[443] \\
0.304 \\
0.267 \\
12831.9\end{array}$ & $\begin{array}{c}85[974] \\
0.756 \\
0.749 \\
26979.5\end{array}$ & $\begin{array}{c}0.000 \\
0.813 \\
0.0252 \\
0.246 \\
72\end{array}$ & $\begin{array}{c}\cdot . \\
0.000 \\
0.480 \\
0.160 \\
0.804 \\
93\end{array}$ \\
\hline
\end{tabular}

Standard errors in parentheses; ${ }^{*} p<0.1,{ }^{* *} p<0.05,{ }^{* * *} p<0.01$; hansenp represents the p-value of the Hansen test of overid. restrictions; sarganp represents the p-value of the Sargan test of overid. restrictions; ar1p and ar2p represent the p-values of the autocorrelation tests of order 1 and 2 respectively; "Inc" refers to incentive regulation and "RoR" to RoR regulation; Note that year dummies were included in all presented specifications.

Table A7a: Smoothing (S), Impact (I) and Target Payout (Tpr) using Net Profits

\begin{tabular}{lcc|cc|cc}
\hline & \multicolumn{2}{c|}{ OLS } & \multicolumn{2}{c|}{ FE } & \multicolumn{2}{c}{ GMM } \\
\hline \multicolumn{1}{c}{ Inc } & Cost & Inc & Cost & Inc & Cost \\
\hline $\mathrm{S}$ & 0.303 & $0.644^{* * *}$ & 0.0558 & $0.610^{* * *}$ & $0.446^{*}$ & $0.761^{* * *}$ \\
$\mathrm{I}$ & $0.403^{* * *}$ & $0.234^{* * *}$ & $0.285^{* * *}$ & $0.233^{* * *}$ & $0.377^{* * *}$ & $0.115^{*}$ \\
$\mathrm{Tpr}$ & $0.578^{* * *}$ & $0.656^{* * *}$ & $0.302^{* * *}$ & $0.599^{* * *}$ & $0.681^{* * *}$ & $0.480^{*}$ \\
\hline
\end{tabular}


Table A8: Incentive vs Cost-Based Regulation - Analysis by sub-sampling - Cash Flows

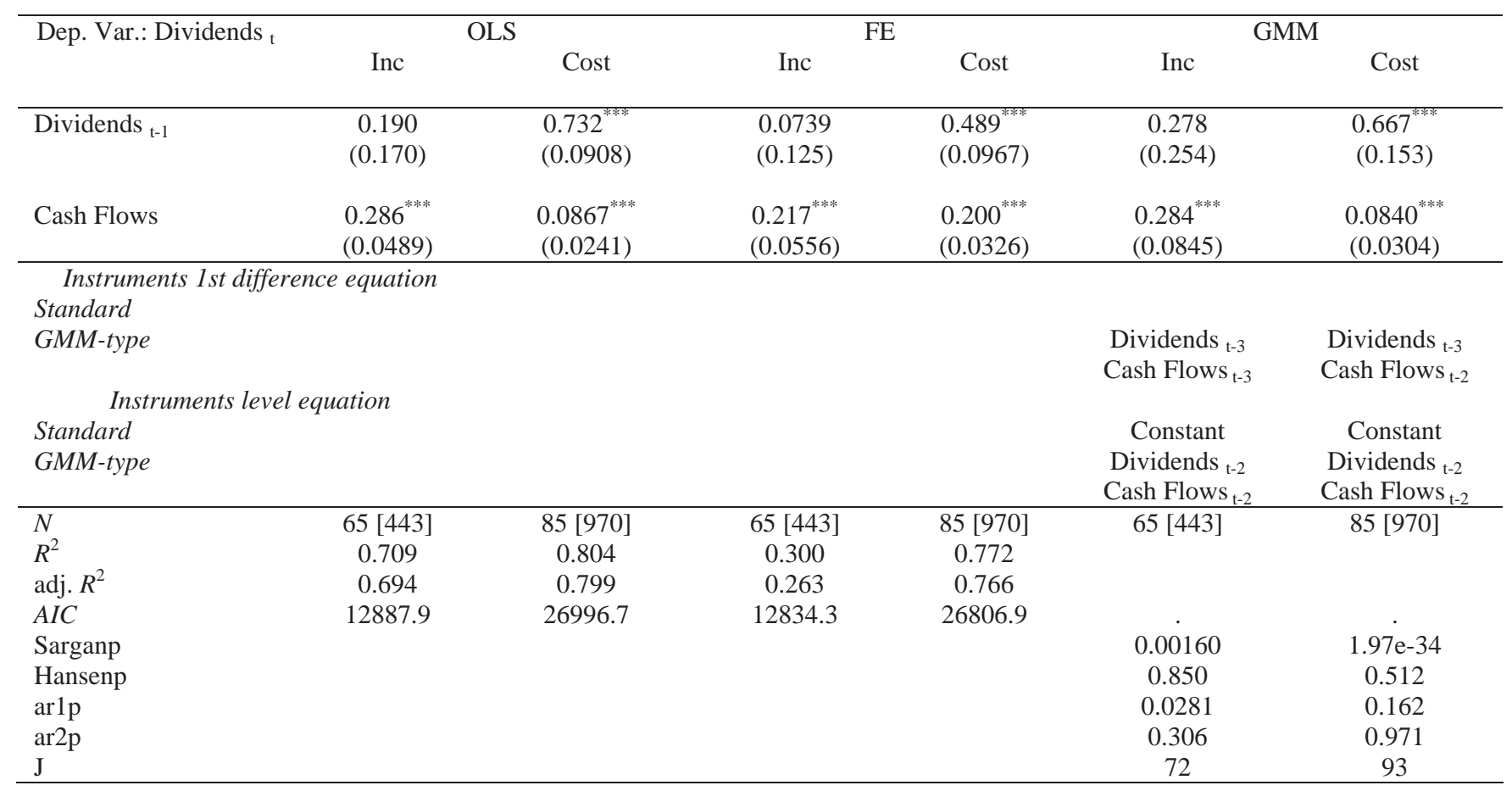

Standard errors in parentheses; ${ }^{*} p<0.1,{ }^{* *} p<0.05,{ }^{* * *} p<0.01$; hansenp represents the $\mathrm{p}$-value of the Hansen test of overid. restrictions; sarganp represents the p-value of the Sargan test of overid. restrictions; ar1p and ar2p represent the p-values of the autocorrelation tests of order 1 and 2 respectively; "Inc" refers to incentive regulation and "RoR" to RoR regulation; Note that year dummies were included in all presented specifications.

Table A8a: Smoothing (S), Impact (I) and Target Payout Ratio (Tpr)

\begin{tabular}{|c|c|c|c|c|c|c|}
\hline & \multicolumn{2}{|c|}{ OLS } & \multicolumn{2}{|c|}{$\mathrm{FE}$} & \multicolumn{2}{|c|}{ GMM } \\
\hline & Inc & Cost & Inc & Cost & Inc & Cost \\
\hline $\mathrm{S}$ & 0.190 & $0.732 * * *$ & 0.0739 & $0.489 * * *$ & 0.278 & $0.667 * * *$ \\
\hline I & $0.286 * * *$ & $0.0867 * * *$ & $0.217 * * *$ & $0.200 * * *$ & $0.284 * * *$ & $0.0840 * * *$ \\
\hline $\mathrm{Tpr}$ & $0.353 * * *$ & $0.324 * * *$ & $0.235^{* * *}$ & $0.391 * * *$ & $0.393 * * *$ & $0.252 * * *$ \\
\hline
\end{tabular}


Authors contacts:

\section{Francisca Bremberger}

WU Vienna University of Economics and Business

Institute of Corporate Governance

Nordbergstrasse 15,

1090 Vienna

Austria

Email: Francisca.Bremberger@wu.ac.at

\section{Carlo Cambini}

Politecnico di Torino, DIGEP

Corso Duca degli Abruzzi, 24

I-10129 Torino

European University Institute

Florence School of Regulation

Via Boccaccio, 151

I-50133 Firenze

Email: carlo.cambini@polito.it

\section{Klaus Gugler}

WU Vienna University of Economics and Business, Institute for Quantitative Economics

Augasse 2-6

1090 Vienna

Austria

Email: Klaus.Gugler@wu.ac.at

\section{Laura Rondi (Corresponding author)}

Politecnico di Torino, DIGEP

Corso Duca degli Abruzzi, 24

I-10129 Torino

Email: laura.rondi@polito.it 